\title{
CATALYST AND REACTOR DEVELOPMENT FOR A LIQUID PHASE FISCHER-TROPSCH PROCESS
}

Quarterly Technical Progress Report for January 1-March 31, 1982

By

Paul N. Dyer

Ronald Pierantozzi

Barry W. Brian

Jeffrey V. Bauer

April 1982

Work Performed Under Contract No. AC22-80PC30021

Air Products and Chemicals, Inc.

Allentown, Pennsylvania

\section{U. S. DEPARTMENT OF ENERGY}




\section{DISCLAIMER}

This report was prepared as an account of work sponsored by an agency of the United States Government. Neither the United States Government nor any agency Thereof, nor any of their employees, makes any warranty, express or implied, or assumes any legal liability or responsibility for the accuracy, completeness, or usefulness of any information, apparatus, product, or process disclosed, or represents that its use would not infringe privately owned rights. Reference herein to any specific commercial product, process, or service by trade name, trademark, manufacturer, or otherwise does not necessarily constitute or imply its endorsement, recommendation, or favoring by the United States Government or any agency thereof. The views and opinions of authors expressed herein do not necessarily state or reflect those of the United States Government or any agency thereof. 


\section{DISCLAIMER}

Portions of this document may be illegible in electronic image products. Images are produced from the best available original document. 


\title{
DISCLAIMER
}

\begin{abstract}
"This report was prepared as an account of work sponsored by an agency of the United States Government. Neither the United States Government nor any agency thereof, nor any of their employees, makes any warranty, express or implied, or assumes any legal liability or responsibility for the accuracy, completeness, or usefulness of any information, apparatus, product, or process disclosed, or represents that its use would not infringe privately owned rights. Reference herein to any specific commercial product, process, or service by trade name, trademark, manufacturer, or otherwise, does not necessarily constitute or imply its endorsement, recommendation, or favoring by the United States Government or any agency thereof. The vicws and opinions of authors expressed herein do not necessarily state or reflect those of the United States Government or any agency thereof."
\end{abstract}

This report has been reproduced directly from the best available copy.

Available from the National Technical Information Service, U. S. Department of Commerce, Springfield, Virginia 22161.

Price: Printed Copy A04 Microfiche A01

Codes are used for pricing all publications. The code is determined by the number of pages in the publication. Information pertaining to the pricing codes can be found in the current issues of the following publications, which are generally available in most libraries: Energy Research Abstracts, (ERA); Government Reports Announcements and Index (GRA and I); Scientific and Technical Abstract Reports (STAR); and publication, NTIS-PR-360 available from (NTIS) at the above address. 


\author{
Catalyst and Reactor Development for a Liquid Phase \\ Fischer-Tropsch Process \\ Quarterly Technical Progress Report \\ For Period 1 January 1982 - 31 March 1982
}

Paul N. Dyer

Ronald Pierantozzi

Barry W. Brian

Jeffrey V. Bauer

Air Products and Chemicals, Inc.

Allentown, PA 18105

April 1982

Prepared for United States Department of Energy

Under Contract No. CE-AC22-80PC 30021 
THIS PAGE

\section{WAS INTENTIONALLY \\ LEFT BLANK}




\section{AdirProducts}

\section{ABSTRACT}

This report describes work carried out in the sixth quarter of a three year contract, begun October 1980, between Air Products and Chemicals, Inc. and the DOE: "Catalyst and Reactor Development for a Liquid Phase FischerTropsch Process". The proyram contains four major tasks: (i; Project Work Plan, (2) Slurry Catalyst Development, . ; Slurry Reactor Design Studies, and (4) Pilot Facility Design.

In Task 2, two modified "conventional" catalysts were screened in the gas phase, and the improved results gave directions for further development work.

Three slurry tests were run. The first, a 15 wt\% slurry of a coprecipitated catalyst, showed non-standard Schulz-Flory product distributions, with a significant increase in $\mathrm{C}_{9}+$ hydrocarbons. The second, a 19 wt\% slurry of a supported catalyst, also showed large deviations from the standard Schulz-Flory product, with a high solectivity for ${ }^{1} 10^{-C_{2}} 25$ hydrocarbons. Compared to a previous gas phase test, however, $\mathrm{CH}_{4}$ yields were higher and the activity lower. A third slurry test of a supported cluster catalyst also showed a lower activity than in the gas phase.

0 il analysis indicates that the reduction of activity observed for supported metal catalysts in the slurry compared to the gas phase may be due to poisoning by an oil component. An alternative oil will therefore be utilized for future tests.

Seven supported cluster catalysts were synthesized and six were screened in the gas phase. In two cases, an increased yield of $\mathrm{C}_{10^{+}}$products was observed, dependent upon the reaction conditions. Another showed a product selectivity that could be shifted between oxygenates and hydrocarbons.

In Task 3, gas hold-up and solids dispersion measurements in the $5^{11}$ column were completed for the 0-5 $\mu \mathrm{m}$ and 45-53 $\mu \mathrm{m}$ iron oxide/isoparaffin, and the 45-53 $\mu \mathrm{m}$ and 90-115 $\mu \mathrm{m}$ silica/isoparaffin systems. The gas hold-up results were correlated by statistical analysis. Solids dispersion profiles were found to be very non-uniform for the 95-115 $\mu \mathrm{m}$ silica slurry al zero liquid velocity, indicating the $\geqq 100 \mu \mathrm{m}$ particles are not suitable for slurry reactor operation with internal heat transfer.

Shakedown runs were conducted on the liquid axial dispersion measurement system, and construetion of the $12^{\prime \prime}$ column was begun. 
1.0 INTRODUCTION

2. 0 OBJECTIVE

3.0 SUMMARY AND CONCLUSIONS

3.1 Task 1 - Project Work Plan.

2

3.2 Task 2 - Slurry Catalyst Development - 3

3.2.1 Sub-Task 2a - Background Studies 3

3.2.2 Sub-Task 2b - Bench Scale Reactor Set-Up 3

3.2.3 Sub-Task 2c - Catalyst Preparation and 3 Slurry Reactor Tests

3.2.4 Sub-Task 2d - Metal Cluster Catalyst 3

Preparation and Screening Tests

3.3. Task 3 - Slurry Reactor Design Studies 3

4.0 . ACKNOWLEDGEMENTS : 4

5.0 RESULTS AND DISCUSSION 4

5.1 Task 1 - Project Work Plan 4

5.2 Task 2 - Slurry Catalyst Development 4

5.2.1 Sub=Task 2a - Background Studles 4

5.2.2 Sub-Task 2b - Bench Scale Reactor Set-Up 5

5.2.3 Sub-Task 2c - Catalyst Preparation and 5 Slurry Reactor Tests

5.2.4 Sub-Task 2d - Metal Cluster Catalyst 5

Preparation and Screening Tests

5.3 Task 3 - Slurry Reactor Design Studies 5

5.3 .15 " Cold Flow Simulator 5

5.3.2 12" Cold Flow Simulator 9

6.0 EXPERIMENTAL ‘ 9

6.1 Task 1 - Project Work Plan 9

6.2 Task 2 - Slurry Catalyst Development 10

6.2.1 Sub-Task 2a - Background Studies 10

6.2.2 Sub-Task 2b - Bench Scale Reactor Set-Up 10

6.2.3 Sub-Task 2c - Catalyst Preparation and 11 Slurry Reactor Tests 
TABLE OF CONTENTS

(continued)
6.2.4 Sub-Task 2d - Metal Cluster Catalyst Preparation and Screening Tests

Page

11

11

11

11

13

8. 0 FIGURES

43 


\section{TABLE OF CONTENTS}

(continued)

List of Figures

Figure 15 Inch Cold Flow Simulator - Isuparaffin, 0-5 $\mu \mathrm{m}$

Red Iron Oxide, $\mathrm{N}_{2}$

Figure 25 Inch Cold Flow Simulator - Isoparaffin, 45-53 $\mu \mathrm{m}$

Iron Oxide, $\mathrm{N}_{2}$

Figure 35 Inch Cold Flow Simulator - Isoparaffin, 45-53 $\mu \mathrm{m}$ Silica, $\mathrm{N}_{2}$

Figure 45 Inch Cold Flow Simulator - Isoparaffin, 90-115 $\mu \mathrm{m}$ Silica, $\mathrm{N}_{2}$

Figure 55 Inch Cold Flow Simulator - Solid Concentration

Profiles Isoparaffin, $0-5 \mu \mathrm{m}$ Red Iron 0xide, $\mathrm{N}_{2}$, Liquid Flow $=0.0 \mathrm{ft} / \mathrm{sec}$

Figure 65 Inch Cold Flow Simulator - Solid Concentration

Profiles Isoparaffin, 0-5 $\mu \mathrm{m}$ Red Iron 0xide, $\mathrm{N}_{2}$, Liquid Flow $=0.0 \mathrm{ft} / \mathrm{ser}$.

Figure 75 Inch Cold Flow Simulator - Solid Concentration

Profiles Isoparaffin, 0-5 $\mu \mathrm{m}$ Red Iron 0xide, $\mathrm{N}_{2}$, Liquid $\mathrm{Flow}>0.0 \mathrm{ft} / \mathrm{sec}$

Figure 85 Inch Cold Flow Simulator - Solid Concentration

Profiles Isoparaffin, 0-5 $\mu \mathrm{m}$ Red Iron 0xide, $\mathrm{N}_{2}$, Liquid $\mathrm{Flow}>0.0 \mathrm{ft} / \mathrm{sec}$

Figure 95 Inch Cold Flow Simulator - Solid Concentration

Profiles Isoparaffin, 45-53 $\mu \mathrm{m}$ Iron 0xide, $\mathrm{N}_{2}$, Liquid Flow $=0.0 \mathrm{ft} / \mathrm{sec}$

Figure 105 Inch Cold Flow Simulator - Solid Concentration

Profiles Isoparaffin, 45-53 $\mu \mathrm{m}$ Iron 0xide, $\mathrm{N}_{2}$, Liquid Flow $=0.0 \mathrm{ft} / \mathrm{sec}$

Figure 115 Inch Cold Flow Simulator - Solid Concentration

Profiles Isoparaffin, 45-53 $\mu \mathrm{m}$ Iron 0xide, $\mathrm{N}_{2}$, Liquid $\mathrm{Flow}>0.0 \mathrm{ft} / \mathrm{sec}$

Figure 125 Inch Cold Flow Simulator - Solid Concentration

Profiles Isoparaffin, 45-53 $\mu \mathrm{m}$ Silica, $\mathrm{N}_{2}$, Liquid $\mathrm{Flow}=0.0 \mathrm{ft} / \mathrm{sec}$ 


\section{TABLE OF CONTENTS}

(continued)

List of Figures (continued)

Figure 13 5. Inch Cold Flow Simulator - Solid Concentration

Profiles Isoparaffin, 45-53 $\mu \mathrm{m}$ 'Silica,

$\mathrm{N}_{2}$, Liquid Flow $=0.0 \mathrm{ft} / \mathrm{sec}$

Figure 145 Inch Cold Flow Simulator - Solid Concentration

Profiles Isoparaffin, 45-53 $\mu \mathrm{m}$ Silica,

$\mathrm{N}_{2}$, Liquid Flow $>0.0 \mathrm{ft} / \mathrm{sec}$

Figure 155 Inch Cold Flow Simulator - Solid Concentration

Profiles Isoparaffin, 45-53 $\mu \mathrm{m}$ Silica,

$\mathrm{N}_{2}$, Liquid $\mathrm{Flow}>0.0 \mathrm{ft} / \mathrm{sec}$

Figure 165 Inch Cold Flow Simulator - Solid Concentration

Profiles Isoparaffin, 98-115 $\mu \mathrm{m}$ Silica, $\mathrm{N}_{2}$, Liquid $\mathrm{Flow}=0.0 \mathrm{ft} / \mathrm{sec}$

Figure 175 Inch Cold Flow Simulator - Solid Concentration

Profiles Isoparaffin, 98-115 $\mu \mathrm{m}$ Silica,

$\mathrm{N}_{2}$, Liquid Flow $>0.0 \mathrm{ft} / \mathrm{sec}$

Figure 185 Inch Cold Flow Simulator - Solid Concentration

Profiles Isoparaffin, 98-115 $\mu \mathrm{m}$ Silica, $\mathrm{N}_{2}$, Liquid Flow $>0.0 \mathrm{ft} / \mathrm{sec}$

Figure 19 Conductivity Signal Filtering Experiments - 6962-68-1 32

Figure 20 Conductivity Signal Filtering Experiments - 6962-68-2 33

Figure 21 Conductivity Signal Filtering Experiments - 6962-68-3 34

Figure 22 Conductivity Signal Filtering Experiments - 6962-68-4 35

Figure 23 Conductivity Signal Filtering Experiments - 6962-68-5 36

Figure 24 Conductivity Signal Filtering Experiments - 6962-68-2a 37

Figure 25 Conductivity Signal Filtering Experiments - 6962-68-2b 38

Figure 26 Conductivity Signal Filtering Experiments - 6962-68-2c 39

Figure 275 Inch Cold Simulator Dispersion Coefficient vs Gas 40

$\begin{array}{lll}\text { Figure } 28 & \text { Primary Alcohol Standard } & 41\end{array}$

Figure 29 Hydrocarbon Product with Primary Alcohols Overlayed 42 


\section{TABLE OF CONTENTS}

(continued)

List of Tables

Page

Table 1 Gas Hold-Up: 5" Cold Flow Simulator, Three Phase System 44 Liquid: Isoparaffin, Solid: 0-5 $\mu \mathrm{m}$ Red Iron Oxide, Gas: Nitrogen

Table 2 Gas Hold-Up: 5" Cold Flow Simulator, Three Phase System

Liquid: Isoparaffin, Solid: 45-53 $\mu \mathrm{m}$ Iron Oxide, Gas: Nitrogen

Table 3 Gas Hold-Up: 5" Cold Flow Simulator, Three Phase System

Liquid: Isoparaffin, Solid: 45-53 $\mu \mathrm{m}$ Silica, Gas: Nitrogen

Table 4 Gas Hold-Up: 5" Cold Flow Simulator, Three Phase System 50. Liquid: Isoparaffin, Solid: 90-116 $\mu \mathrm{m}$ Silica, Gas: Nitrogen

Table 5 Literature Comparison for Shielded, Internal Probes in 52 5" Column 


\subsection{INTRODUCTION}

Coal liquefaction will be an important source of transportation fuels in the future, and can be accomplished by both the direct route (hydrogenation of coal in a donor solvent) or by an iriuirect route (gasification of coal followed by the Fischer-Tropsch reaction).

The product selectivity of the Fischer-Tropsch reaction has been the focus of extensive research for many years, yet still remains a prime target for technical innovation. Fischer-Tropsch technology, as it is currently practiced commercially for liquid fuels production, provides a broad range of hydrocarbon products which require costly downstream refining.

Selectivity can be influenced by variations in the catalyst composition and process conditions. Yet, in spite of the extensive effort devoted to this problem, a suitable catalyst has not previously been developed for producing a narrow range hydrocarbon product such as gasoline or diesel fuel without the coproduction of lighter and heavier undesirable products.

The Fischer-Tropsch reaction is also exothermic, and improved heat transfer would also be expected to have a major beneficial effect on product selectivity. Slurry phase reactor operation improves heat transfer and temperature control, and results in greater selectivity to liquid products, usually through lower methane production. However, considerable differences have been reported in the space-time yield, catalyst life and ease of operation of slurry phase reactors.

In addition to improved product selectivity, slurry phase operation offers the advantage of ease of scale-up and the ability to directly utilize the carbon monoxide-rich synthesis gas produced by coal gasifiers. The full potential of the slurry phase Fischer-Tropsch process has not yet been realized, and its further development is an important part in our country's program to establish viable technology for converting coal to hydrocarbon fuels.

Therefore, Air Products (APCI), under contract to the DOE, has undertaken a program in catalyst and reactor development for a slurry phase Fischer-Tropsch process. This contract spans 36 months and is divided into fuir major tasks. This report described the work accom$\dot{p}$ lished during the sixth quarter. 


\section{$\triangle$ Air Products}

\subsection{OBJECTIVE}

The overall objective of this program is to evaluate catalysts and slurry reactor systems for the selective conversion of synthesis gas into transportation fuels via a single stage, liquid phase procsis.

Task 1 - To establish a detailed Project Work Plan.

Task 2 - To evaluate and test catalysts for their potential to convert synthesis gas to gasoline, diesel fuel, or a mixture of transportation fuels suitable for domestic markets, and to quantify catalyst activity, selectivity, stability and aging with a target process concept involving a single stage, liquid phase reactor system.

Task 3 - To evaluate through the use of cold-flow reactor simulators the flow characteristics and behavior of slurry reactors for the production of hydrocarbons from synthesis gas. This includes (1) defining heat, mass and momentum transfer parameters which effect the design of slurry reactors, (2) establish operating limits for slurry reactors with respect to system physical parameters, (3) developing or confirming correlations for predicting the flow characteristics and heat/mass transfer of slurry reactors, and (4) defining the necessary requirements for the design of larger scale reactors.

Task 4 - To develop a preliminary design for a pilot plant slurry phase Fischer-Tropsch reactor.

\subsection{SUMMARY AND CONCLUSIONS}

\subsection{Task 1 - Project Work Plan}

This task was completed in the first quarter. 


\section{A Air Products}

\subsection{Task 2 - Slurry Catalyst Development}

\subsubsection{Sub-Task 2a - Background Studies}

A computerized survey of available literature and patents dealing with the conventional and slurry phase Fischer-Tropsch processes and the hydrodynamics of three phase slurry reactors was continued.

\subsubsection{Sub-Task 2b - Bench Scale Reactor Set-Up}

This sub-task was completed with the utilization of all three slurry reactors.

The absence of a significant concentration of primary n-alcohols in selected hydrocarbon product samples was confirmed by gc analysis.

\subsubsection{Sub-Task 2c - Catalyst Preparation and Slurry Reactor Testing}

This section contains potentially patentable material and has therefore been issued in a supplementary report marked "Not For Publication".

\subsubsection{Sub-Task 2d - Metal Cluster Catalyst Preparation and Screening Tests}

This section contains potentially patentable material and has therefore been issued in a supplementary report marked "Not For Publication".

\subsection{Task 3 - Slurry Reactor Design Studies}

Gas hold-up and solids dispersion measurements were completed for the 0-5 $\mu \mathrm{m}$ and 45-53 $\mu \mathrm{m}$ iron oxide/isoparaffin, and the 45-53 $\mu \mathrm{m}$ and 90-115 $\mu \mathrm{m} \mathrm{silica/isoparaffin} \mathrm{systems,} \mathrm{in} \mathrm{the} 5 "$ column.

The gas hold-up results were correlated by statistical analysis. An increase of slurry weight percent and density was found to decrease gas holdup in the silica based systems, but had little or no effect in the iron-oxide systems. One reason for this difference could lie in the dependence of slurry viscosity upon weight loading. 
The effect of liquid velocity on solid dispersion becomes more pronounced with increasing weight loading and particle diameter. With the 95-115 $\mu \mathrm{m}$ silica/isoparaffin system, a very non-uniform dispersion profile was observed at zero liquid velocity. Taken in conjunction with the iron-oxide results for this size range reported in the previous quarter, it is concluded from the solid dispersion data that the use of $\geqq 100 \mu \mathrm{m}$ particles is not suitable for slurry reactor operation with internal heat transfer, and is barely acceptable for operation with external heat transfer using higher liquid flows.

Shakedown runs were performed on the liquid axial dispersion measurement system using a two phase air/water system in batch mode. The conductivity probes required shielding with nylon mesh to reduce bubble impingement noise, and the remaining noise, which increased with increasing gas velocity, was filtered out mathematically. Shakedown tests were also carried out on a submerged oxygen probe in an iron oxide/water/air system to measure mass transfer coefficients.

The construction of the $12^{\prime \prime}$ cold flow simulator was begun.

\subsection{ACKNOWLEDGEMENTS}

The contributions to this program by T. G. Dunlap, J. M. LaBar, M. L. Morris, L. E. Schaffer and E. G. Valagene are gratefully acknowledged.

5. 0 RESULTS AND DISCUSSIONS

5.1 Task 1 - Project Work Plan

This task was completed in the first quarter.

\subsection{Task 2 - Slurry Catalyst Development}

\subsubsection{Sub-Task 2a - Background Studies}

Background studies, including a computerized search of current literature and patents, were continued this quarter. 


\section{AdirProducts}

\subsubsection{Sub-Task 2b - Bench Scale Reactor Set-Up}

Instrumentation and shakedown tests were finalized for the $1000 \mathrm{~mL}$ and second $300 \mathrm{~mL}$ slurry reactors. With the utilization of all three slurry reactors for testing, this sub-task is now complete.

Aqueous phase samples from one of the slurry tests, indicated an increased concentration of primary n-alcohols. Since higher molecular weight alcohols would be more soluble in the hydrocarbon phase of the Fischer-Tropsch product, organic phase samples were reexamined by gc to determine their alcohol content. No significant concentration was found.

\subsubsection{Sub-Task $2 c$ - Catalyst Preparation and Slurry Reactor Testing}

This section contains potentially patentable material and has therefore been issued in a supplementary report marked "Not For Publication".

\subsubsection{Sub-Task 2d - Metal Cluster Catalysts Preparation and Screening Tests}

This section contains potentially patentable material and has therefore been issued in a supplementary report marked "Not For Publication".

\section{3 Task 3 - Slurry Reactor Design Studies}

\subsubsection{5" Cold Flow Simulator}

(i) Gas Hold-Up In Isoparaffin

The experimental runs were completed for the 0-5 $\mu \mathrm{m}$ and 45-53 $\mu \mathrm{m}$ iron oxide systems and the 45-53 $\mu \mathrm{m}$ and 90-115 (nominal size) $\mu \mathrm{m}$ silica systems and are included in Tables 1-4 and Figures 1-4, respectively. This completes the gas hold-up measurements in the $5^{\prime \prime}$ column. 


\section{$\triangle$ Adir Productats}

Statistical analysis of the isoparaffin/iron oxide system yielded the following preliminary correlation with a goodness of fit, $r^{2}=0.851$

$$
\varepsilon_{g} /\left(1-\varepsilon_{g}\right)^{4}=1.09 v_{G}^{0.98} D_{P} 0.075
$$

Statistical analysis of the isoparaffin/silica system including the 2 phase and 0-5 $\mu$ m runs yieided the following preliminary correlation, with a goodness of fit $r^{2}=0.1$.

$$
\varepsilon_{g} /\left(1-\varepsilon_{g}\right)^{4}=1.70 \mathrm{~V}_{G}^{1.01_{D_{P}}} 0.12 / \mathrm{W}^{0.27} \rho_{\mathrm{SL}} 0.28
$$

Because the weight percent, $W$, and slurry density,

$\rho_{\text {SL }}$, are related by

$$
\rho_{S L} \equiv W\left(\rho_{S}-\rho_{L}\right)+\rho_{L}
$$

the effect of $W$ and $\rho_{S L}$. will be combined in subsequent correlations, and it is expected that this will change the values of the exponents.

There are several differences between equations (1) and (2). The values of $\rho_{S L}$ and $W$ have little or no effect on gas hold-up in the iron oxide system and a large effect on gas hold-up in the silica system. One reason for this could be a difference between the silica and iron oxide based systems in the dependence of slurry viscosity upon weight loading. It is expected therefore, that the correlation will be improved once slurry viscosity data is available. In addition, the particle size distribution will be more accurately quantified for the 90-115 $\mu \mathrm{m}$ silica.

\section{(ii) Solid Dispersion Results}

Solid concentration profiles for the 0-5 $\mathrm{\mu m}$ red iron oxide system, the 45-53 $\mu \mathrm{m}$ iron oxide and silica systems and the 90-115 $\mu \mathrm{m}$ silica system, are included in Figures 5-8, 9-11, 12-15 and 16-18, respectively.

It is observed that while liquid velocity has little effect on gas hold-up, it has quite a noticeable effect on the solid concentration profiles, and this effect becomes more 
pronounced with increasing weight loading, and particularly, with increasing particle diameter. This work is in agreement with the observations of Sivasubramanian ${ }^{l}$ in their cold flow studies of a hydrogen dissolver, also done at Air Products.

The $98-115 \mu \mathrm{m}$ silica warrants special notice. At zero liquid velocity, a sizable percentage of the silica stayed on the distributor plate. This, in turn, had a detrimental effect on the gas distribution, allowing only a small percentage of the distributor open area to be utilized. The use of $\geqq 100 \mu \mathrm{m}$ particles is, therefore, clearly unacceptable for operation with internal heat transfer (Figure 16) and is barely acceptable for operation with external heat transfer using higher liquid flows. This observation is in agreement with those of Deckwer, et a ${ }^{5}$.

Increasing the gas velocity, does relatively little to suspend the solid (Figures 12-18).

\section{(iii) Liquid Dispersion in Water}

Extensive shakedown runs were performed to determine the system's ability to accurately and reproducibly determine liquid dispersion coefficients, $E_{L}$. All shakedown tests were performed in an air/water system in batch mode. Five runs with $V_{G_{2}}=0.1 \mathrm{ft} / \mathrm{sec}$ gave an average value of $E_{L}{ }^{\circ}=$ $1.65 \times 10^{-2} \mathrm{~m}^{2} / \mathrm{sec}\left(0.178 \mathrm{ft}^{2} / \mathrm{sec}\right)$ with a standard deviation $\alpha=1.28 \times 10^{-3} \mathrm{~m}^{2} / \mathrm{sec}\left(0.014 \mathrm{ft}^{2} / \mathrm{sec}\right)$ see Figures $19-23$. Various shields around the conductivity probe were tried in order to minimize direct bubble impingement on the probe, while allowing liquid to flow freely. The most successful shield to date was a 140 mesh (106 $\mu \mathrm{m}$ ) nylon screen, which was used in all the reported figures. The injection number refers to the number of $50 \mathrm{~mL}$ aliquots of $\mathrm{KCl}$ that were injected in a given liquid batch. 


\section{$\triangle$ Air Products}

For these shakedowns, the data was analyzed using Fick's law analogy as the model,

$$
\frac{\partial C}{\partial t}=E_{L} \frac{\partial^{2} C}{\partial X^{2}}
$$

where $C=$ normalized concentration,

$t=$ time, seconds,

$X=$ distance from the distributor plate, $\mathrm{ft}$

which, following the analytical treatment of Khang and Kuthari ${ }^{6}$, gives the following simple relationship,

$$
E_{L}=L^{2} / 6 \mu
$$

where $L=$ height of aerated liquid, $\mathrm{ft}$

$\mu=$ mean residence time, computed as the area between the residence time distribution, RTD, curve and the maximum normalized concentration line, sec.

Even with the nylon shield, bubble induced noise was present and increased with increasing gas velocity. This remaining noise was mathematically filtered by connecting local maxima on the curve (Figure 24-26). It was necessary to do this mathematical filtering 0-4 times (noted as order of fit in the Figures) depending upon the degree of noise. The dispersion coefficient's reproducibility was greatly improved by this procedure.

Comparing the shakedown runs to the literature, Table 5, Figure 27, the experimental $E_{L} s$ are consistently high except for an anomaly at $0.2 \mathrm{ft} / \mathrm{sec}$ gas velocity. This is because the probe was not at the top of the aerated liquid as required by the analytical treatment of Khang and Kothari. This reduced $\mu$ which, in turn, increased $E_{L}$. Other batch runs will be run with a probe closer to the top of the liquid.

Calculating $E_{L}$ from the intermediate probes poses a different analysis problem. Since no analytical solution was uncovered for intermediate positions in the column, a program to numerically generate those curves from equation (4), 
given the value of $E_{L}$, is being written. By comparing each of the four curves from the four conductivity probes individually, it will be possible to determine whether one value of $E_{L}$ is sufficient to characterize the entire column, or whether separate $E_{L} s$ are required for each section. If $E_{L}$ is dependent upon solid concentration, then $E_{L}$ would not be constant when pronounces solid concentration profiles exist. In this case, obtaining intermediate RTD curves would prove valuable in better characterizing bubble column slurry reactors.

(iv) Oxygen Mass Transfer in Water

A submersible dissolved oxygen probe was successfully tested in a 90-106 $\mathrm{mm}$ iron oxide/water/air system, giving the same response as in a water/air system. A submersible probe is preferable to an external probe in that it allows unsteadystate mass transfer measurements to be taken. Since a zero liquid velocity run at steady-state would soon be completely saturated, no information regarding mass transfer rates would have been obtainable for these conditions. Transient measurements will allow zero liquid flow runs to be analyzed as well as positive flow runs.

\subsubsection{2" Cold Flow Simulator}

(i) 12" Column Construction

All long lead time items arrived and construction of the $12^{\prime \prime}$ column was begun.

\section{0 EXPERIMENTAL}

\section{1 Task 1 - Project Work Plan}

No experimental work. 


\section{AdirProducts}

6.2 Task 2 - Slurry Catalyst Development

\subsubsection{Sub-Task 2a - Background Studies}

No experimental work.

\subsubsection{Sub-Task 2b - Beicil Scale Reactor Set-Up}

Instrumentation and shakedown tests were completed for the $1000 \mathrm{~mL}$ and second $300 \mathrm{~mL}$ slurry reactors.

Several of the analyses of aqueous phase samples demonstrated a trend toward increasing concentrations of long chain primary alcohols. Because of this trend, it was suspected that the organic phase samples associated with these aqueous phase samples might contain significant amounts of $\mathrm{C}_{6}+$ primary alcohols because of their solubility in hydrocarbons and decreasing water solubility. A standard was therefore prepared which contained $C_{6}$ to $C_{11}$ primary alcohols dissolved in hexane. This sample was analyzed by the normal organic phase analysis method. As is shown in Figure 28 , the primary alcohols occur between the normal alkane peaks in the area normally assigned to branched alkanes. Figure 29 shows a superimposition of the alcohol standard on an analysis of an organic phase product sample. The area contribution of these alcohols to this sample is negligible and is typical of those samples analyzed.

Work is currently being conducted to clarify further the contribution of alcohols dissolved in the organic phase. The possibility of derivatizing the alcohols to either shift their retention time or eliminate them from the chromatogram is being considered. Comparison of derivatized and untreated samples would then positively identify . alcoholic species.

A second method utilizing a high pressure liquid chromatograph is also being explored. A high resolution infrared detector will be utilized to identify functional group contributions within the sample. More information on this method will be disclosed in a future report. 


\section{A Air Products}

Samples of the organic phases have been submitted for elemental analysis. The oxygen content of the samples will serve as a check on the total oxygenate concentration present.

\subsubsection{Sub-Task 2c - Catalyst Preparation and Slurry Reactor Tests}

iris section contains potentially patentable material and has therefore been issued in a supplementary report marked "Not For Publication".

6.2.4 Sub -Task 2d - Metal Cluster Catalyst Preparation and Screening Tests

This section contains potentially patentable material and has therefore been issued in a supplementary report marked "Not For Publication".

\subsection{Task 3 - Slurry Reactor Design Studies}

\subsubsection{5" Cold Flow Simulator}

(i) Liquid Dispersion and Mass Transfer in Water

System modifications including the tracer injection system, conductivity and $\mathrm{O}_{2}$ probe ports, and air lines were added to the 5" cold flow simulator. Shakedown runs were carried out as described in section 5.3.1.

\subsection{REFERENCES}

1. Sivasubramanian, R., Ying, D. H. S., and Givens, E. N., Proceedings of the 16th Intersociety Energy Conversion Engineering Conference, Atlanta, 1981, 2, 1092.

2. Akita, K., and Yoshida, Y., Ind. Eng. Chem. Proc. Des. Dev., 1973, 12,76 . 


\section{$\triangle$ Air Products}

3. Hikita, H., and Kikukawa, Chem. Engng. J., 1973, 81, 74.

4. Pilhofer, T. H., Bach, H. F., and Mangartz, K. H., ACS Symp. Ser., $1978,65,372$.

5. Deckwer, W.-D., Louisi, Y., Zaid1, A., and Ralek, M., "Hydrodynamic Properties of the Fischer-Tropsch Slurry Process", Ind. Eng. Chem. Proc. Des. Dev., 1980, 19, 699.

6. Khang, S.-J., and Kothari, S. P., Chem. Eng. Sci., 1980, 35, 2203.

7. Baird, M. H. I., and Rice, R. G., Chem. Eng. J., 1974, 9, 171.

8. Deckwer, W. -D., Burckhart, R., and Zoll, G., Chem. Eng. Sci., $1974,29,2177$.

9. Hikita, H., and Kikukawa, H., Chem. Eng. J., 1974, 9, 191.

10. Kato, Y., and Nishiwaki, A., Int' I Chem. Eng., 1972, 12, 182.

11. Towe 11, G. D., and Ackerman, G. H., European Symposium on Chemical Reaction Engineering, 5th, Amsterdam, 1972, B3-1. 
$\triangle$ Air Products

8. 0 FIGURES

$\therefore$ 


\section{INCH COLD FLOW SIMULATOR}

\section{ISOPARAPFIN, 0-6}

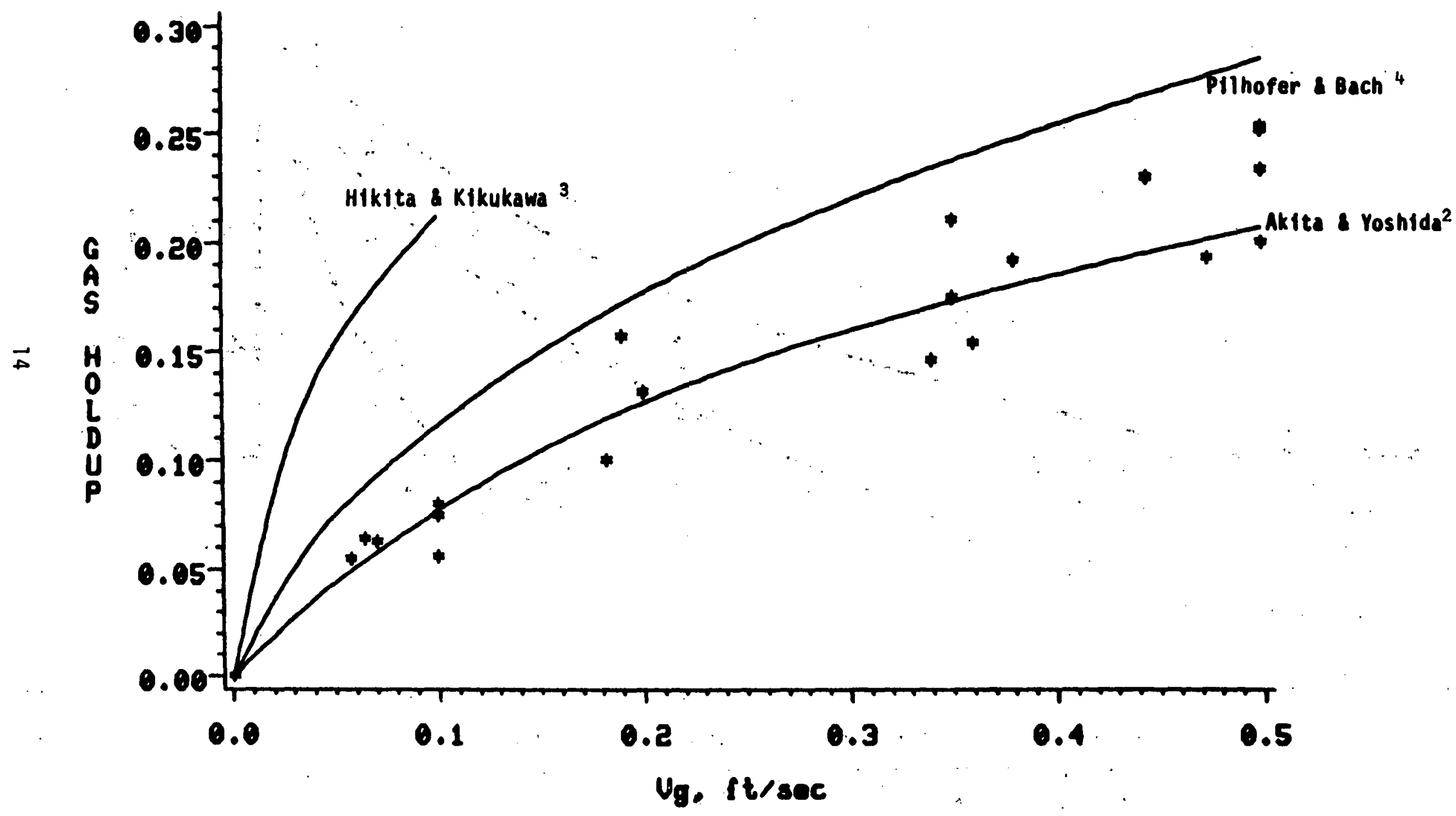




\section{INCH COLD FLOW SIMULATOR} ISOPARAFFIN, 46-53 $\mathrm{M}$ IRON OXIDE,NZ

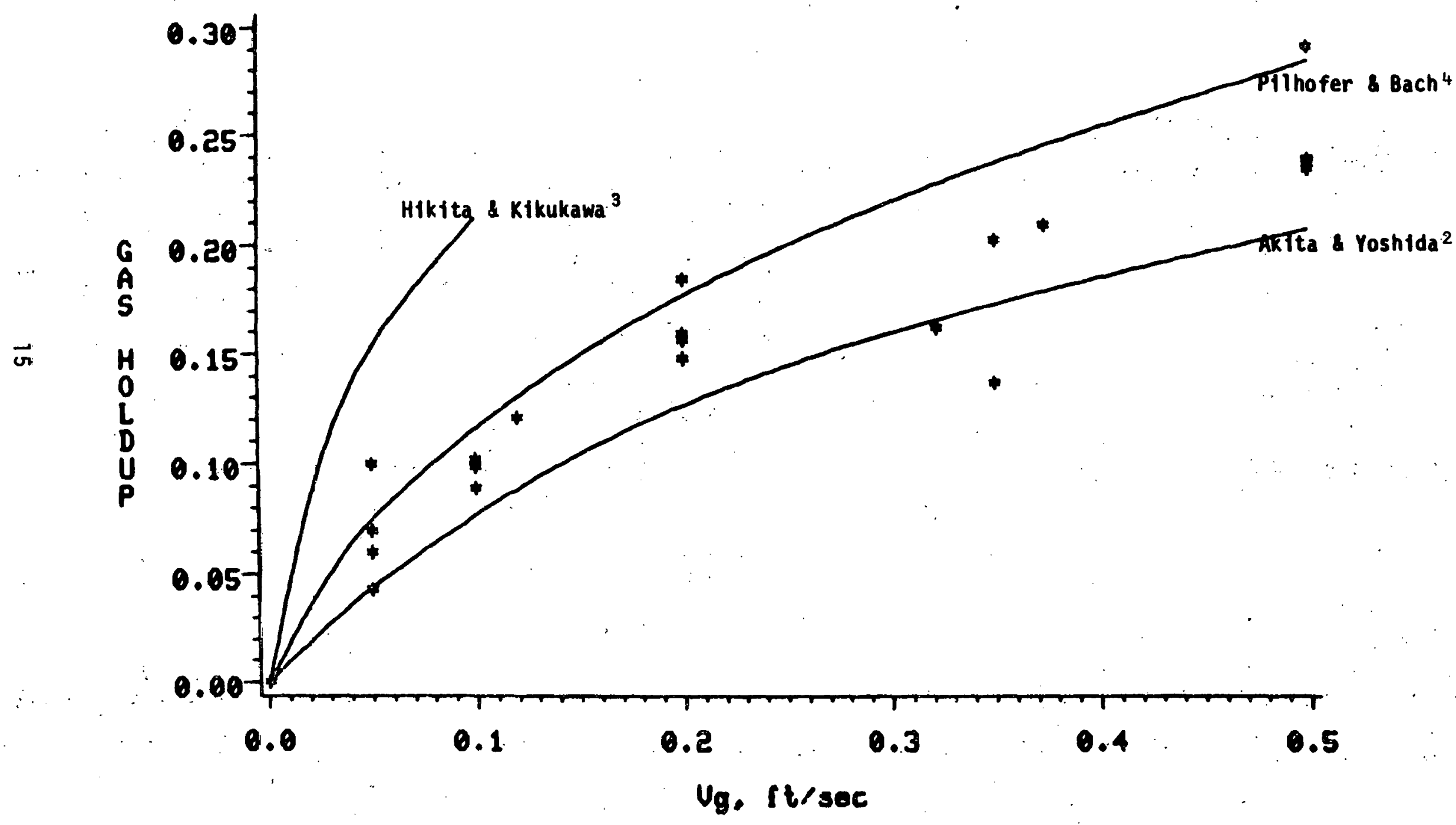


FIGURE 3

\section{INCH COLD FLOW SIMULATOR \\ ISOPARAFFIN, 45-63 $\mu$ M SILICA, N2}

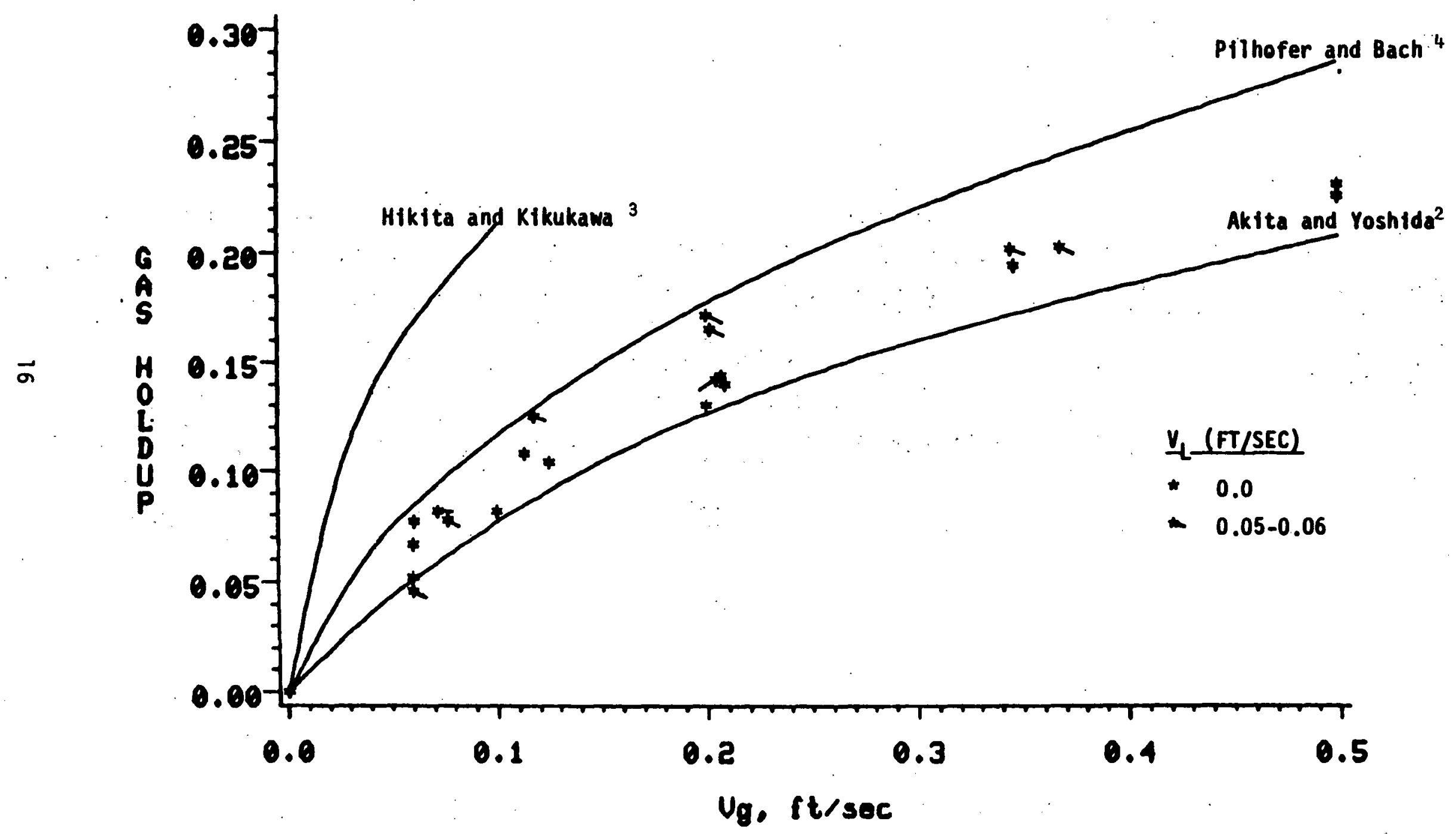




\section{FIGURE 4 \\ 5 INCH COLD FLOW SIMULATOR \\ ISOPARAFFIN, 80-115 $\mu \mathrm{M}$ SILICA, N2}

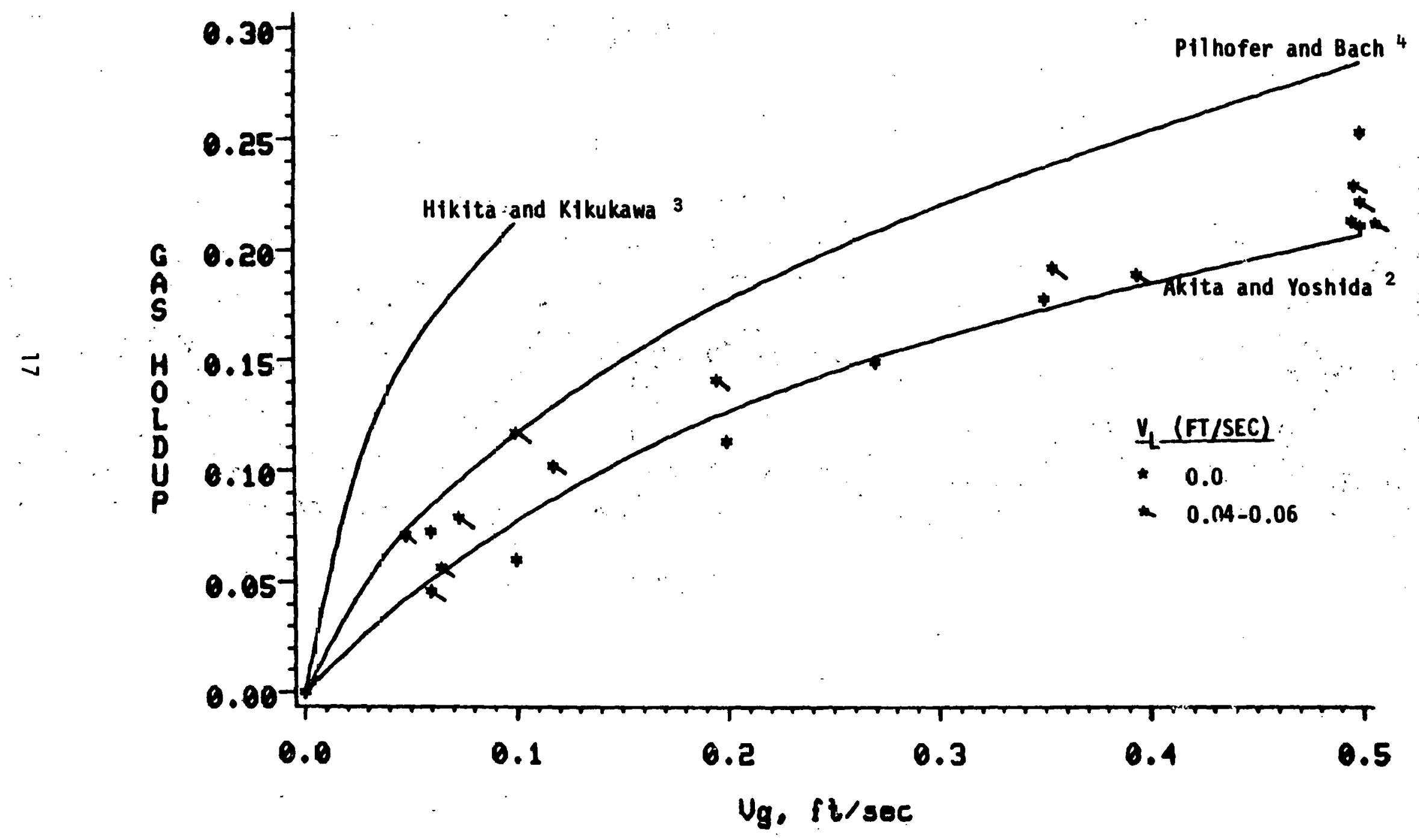


FI GURE 5

\section{INCH COLD FLOW SIMULATOR SOLID CONCENTRATION PROFILES \\ ISOPARAFTIN, 0-5 HM RED IRON OXIDE,N2 \\ LIQUID FLOW $=0.0 \mathrm{PT} / \mathrm{SEC}$}

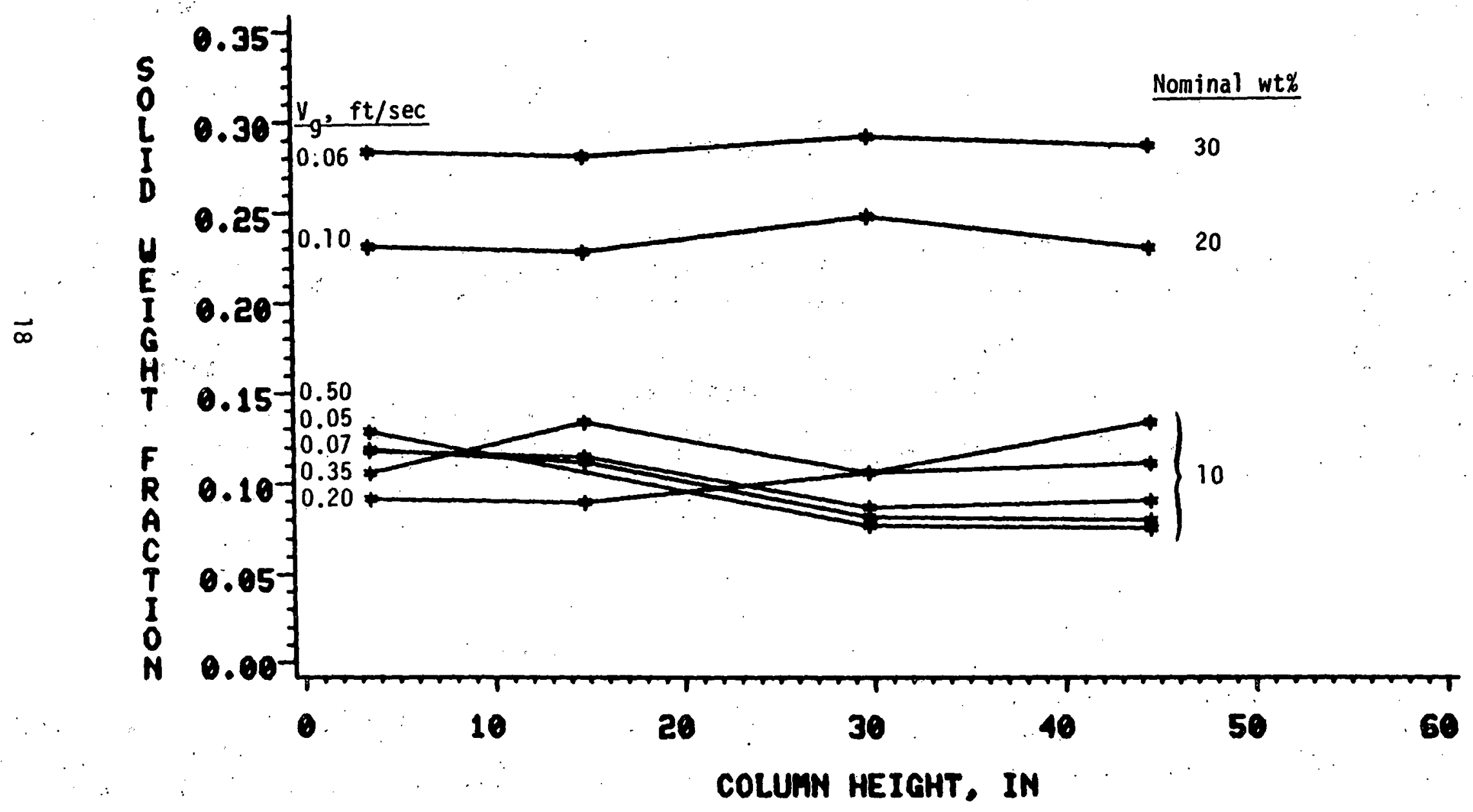




\section{INCH COLD FLOW SIMULATOR SOLID CONCENTRATION PROFILES ISOPARAFFIN, 0-5 $\mu M$ RED IRON OXIDE,N2 LIQUID FLOW $=0.0 \mathrm{FT} / \mathrm{SEC}$}

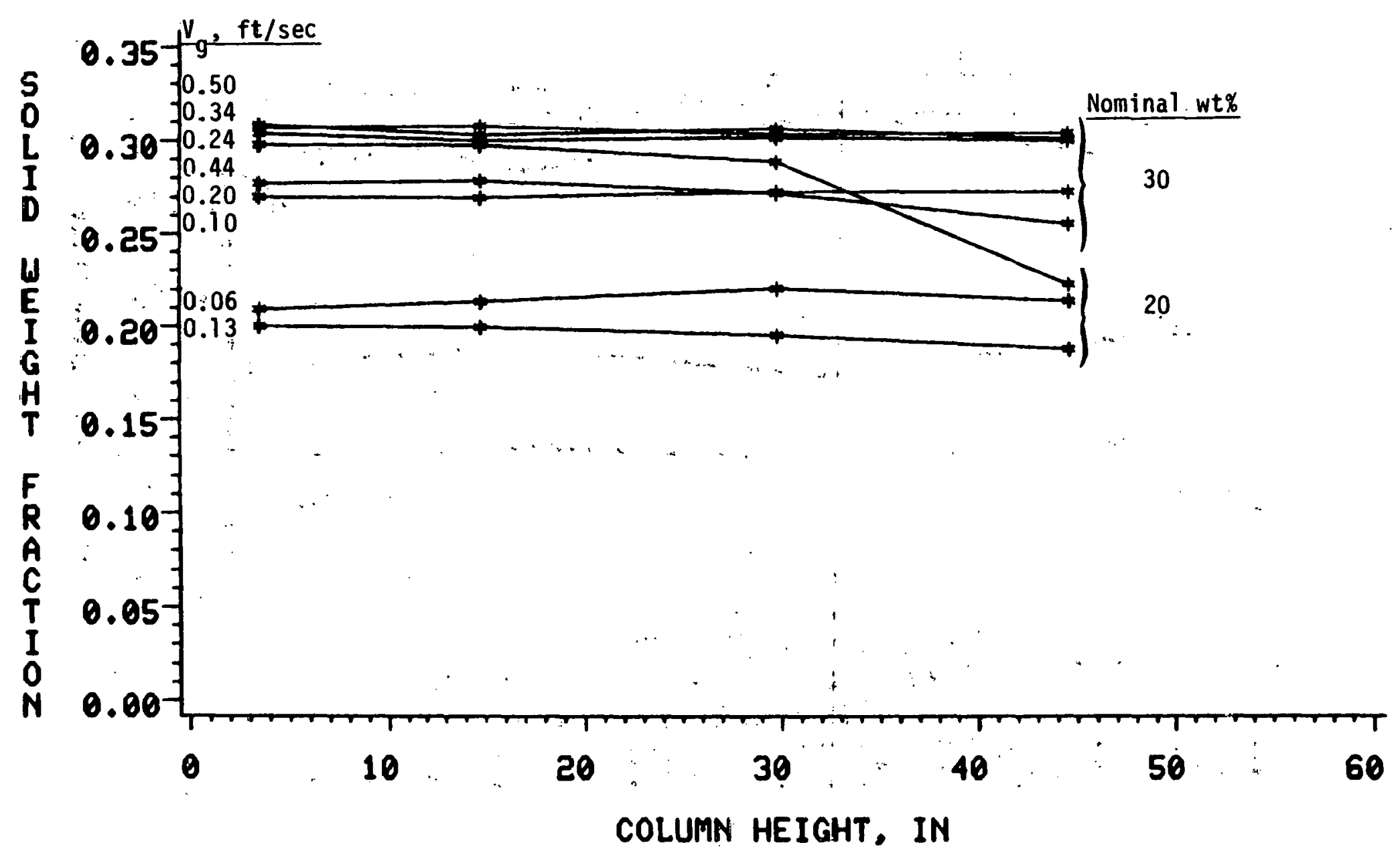




\section{INCH COLD FLOW SIMULATOR} SOLD CONCBNTRATION PROPILES

ISOPARAFPIN, O-5 $4 M$ RBD IRON OXDDE,NE

LUQUID FLON > $0.0 \mathrm{FT} / \mathrm{SZC}$

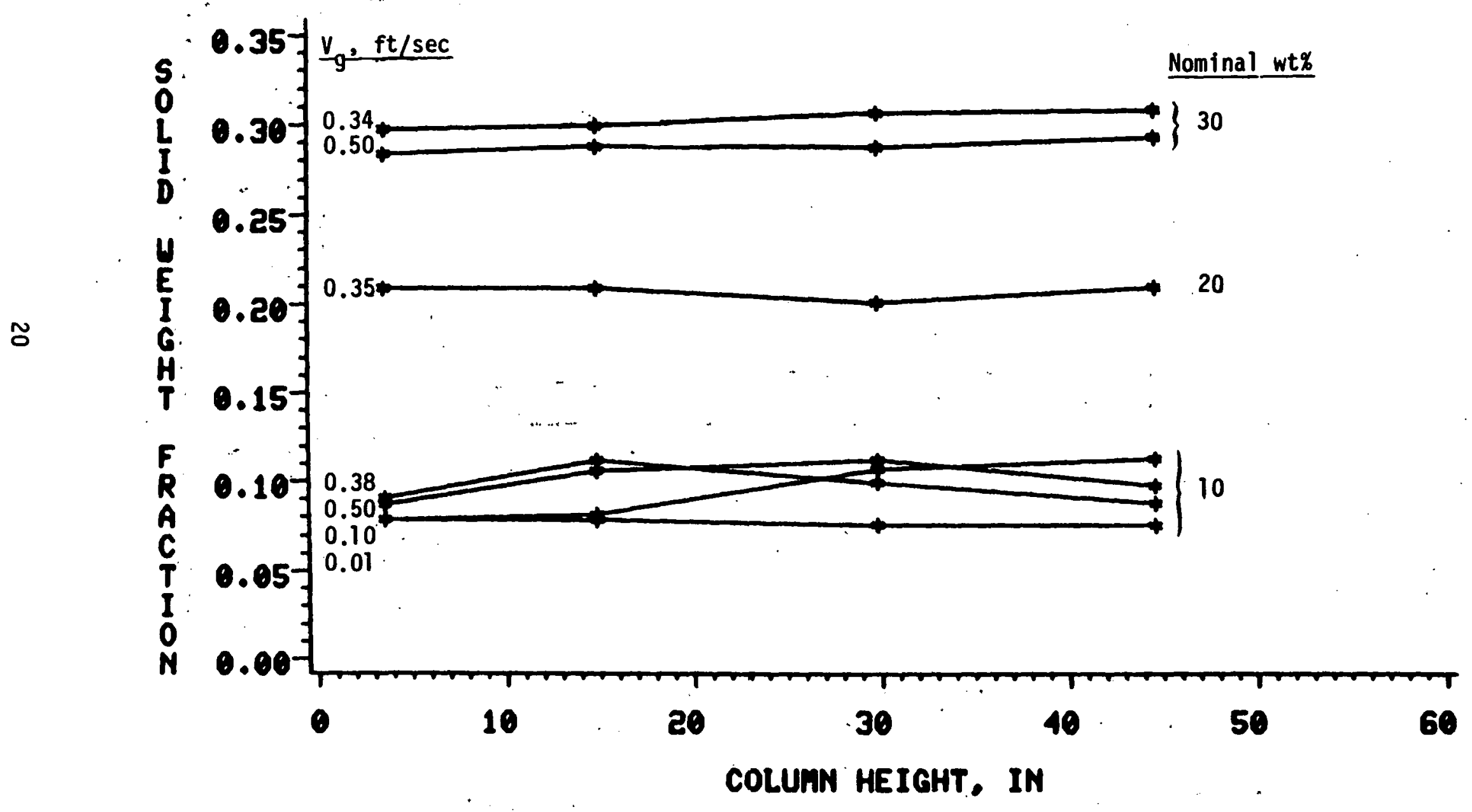




\section{INCH COLD FLOW SIMULATOR SOLID CONCENTRATION PRORILES \\ ISOPARAFTIN, O-5 HM RED IRON OXIDE,N2 LQUID FLOW > $0.0 \mathrm{FT} / \mathrm{SEC}$}

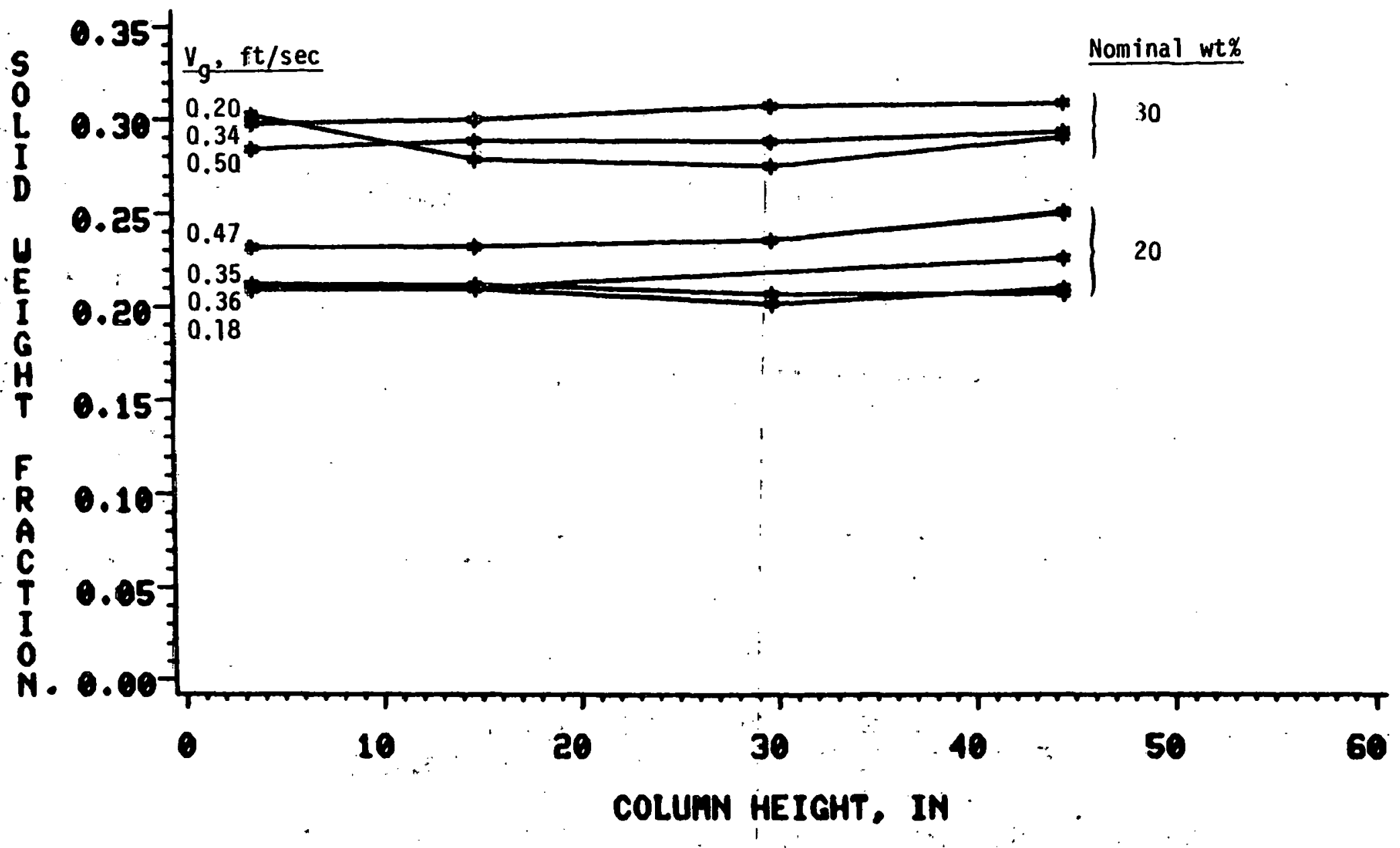


FIGURE 9

\section{INCH COLD FLOW SIMULATOR}

\section{SOLID CONCENTRATION PROPILES}

ISOPARAFTIN, 45-53 „M IRON OXIDE,NZ

LIQUID FLOW $=0.0 \mathrm{FT} / \mathrm{SEC}$

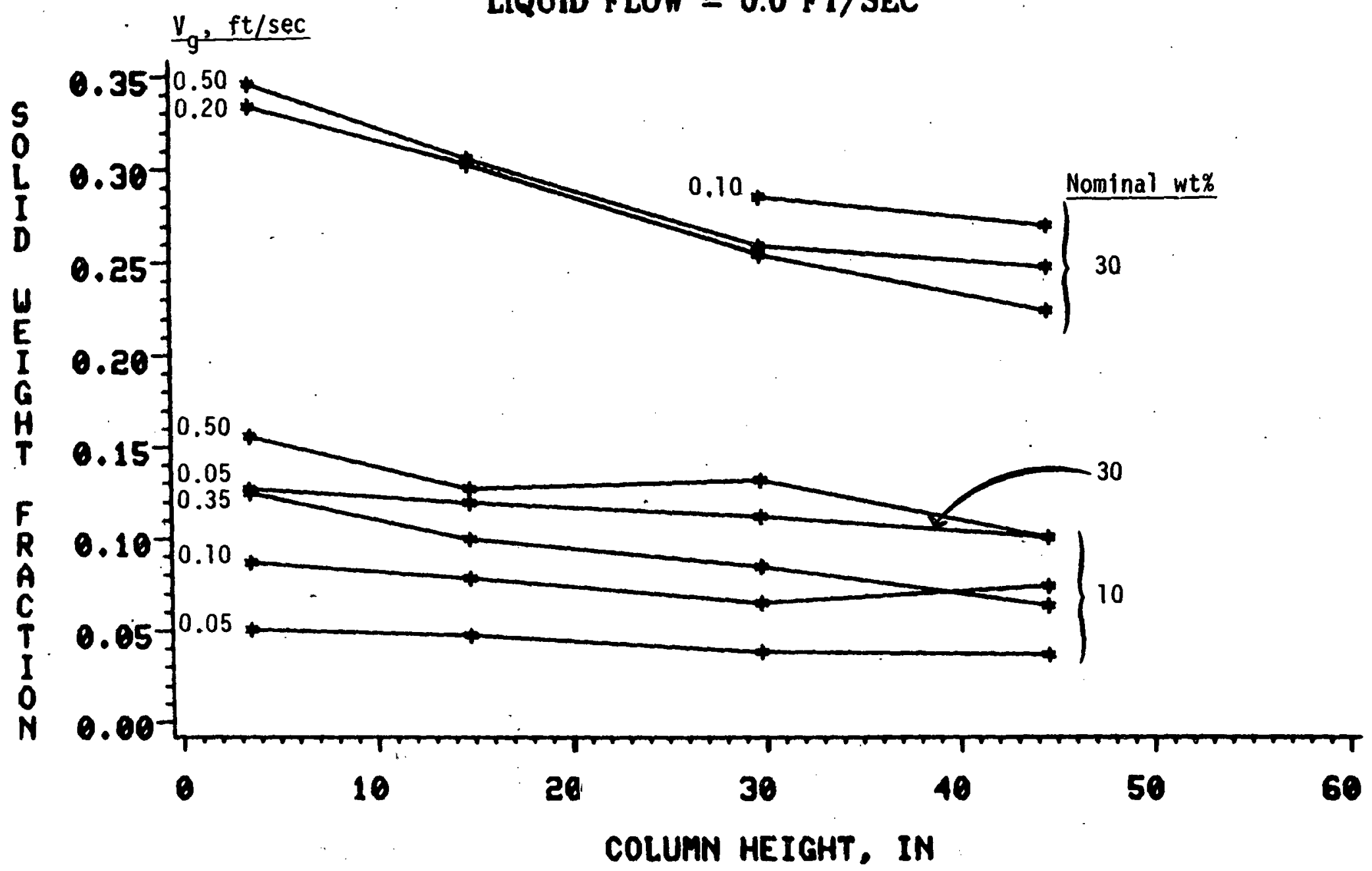




\section{INCH COLD FLOW SIMULATOR} SOLID CONCENTRATION PROPILES

ISOPARAFFIN, 45-59 $\mu M$ IRON OXIDE,N2

$v_{g}, \mathrm{ft} / \mathrm{sec} \quad$ LIQUID FLOW $=0.0 \mathrm{FT} / \mathrm{SEC}$

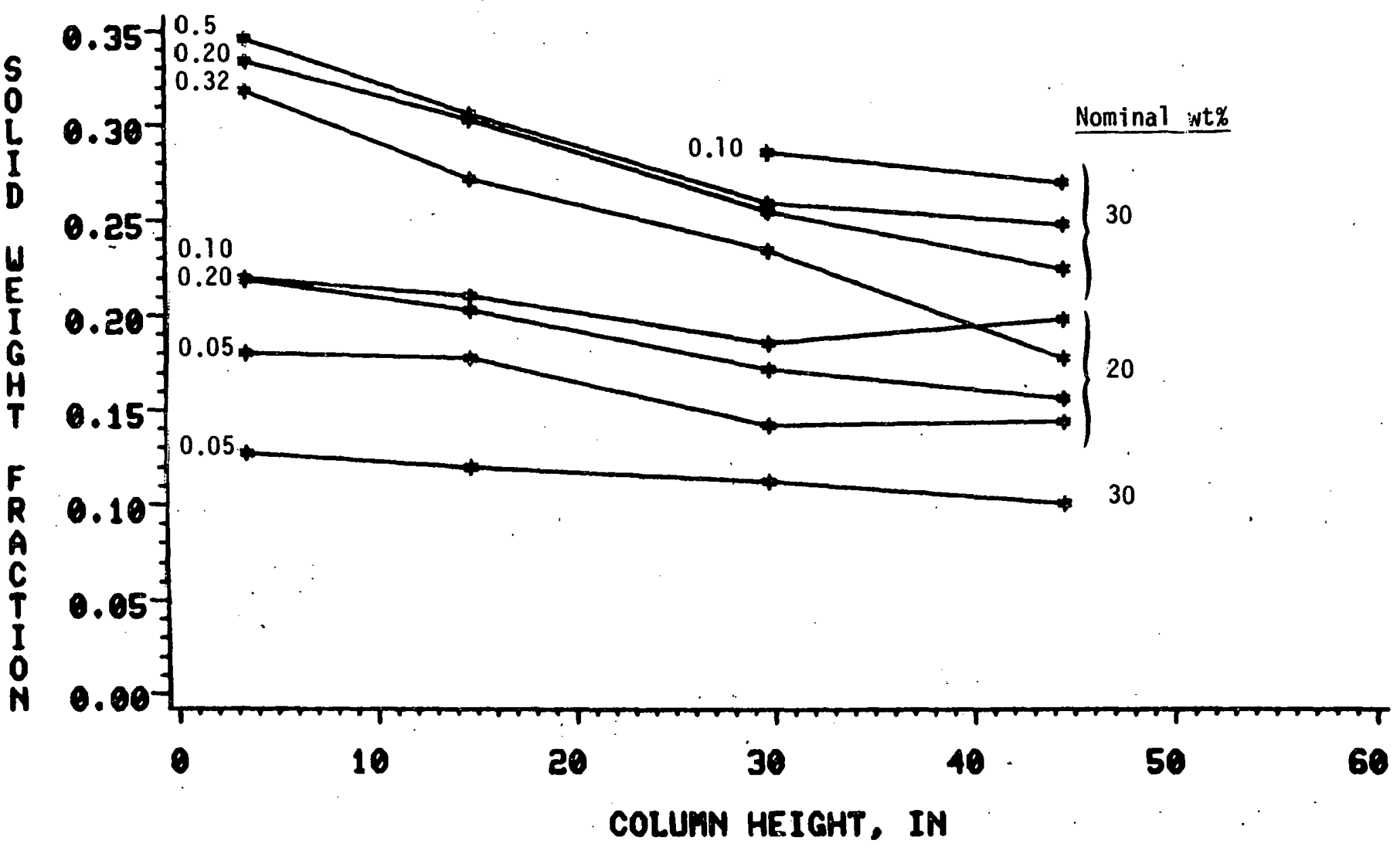




\section{INCH COLD FLOW SIMULATOR SOLID CONCENTRATION PROPILES \\ ISOPARAFTIN, 45-53 $\mu$ M IRON OXIDE,N2 \\ LQUID FLOW > $0.0 \mathrm{FT} / \mathrm{SEC}$}

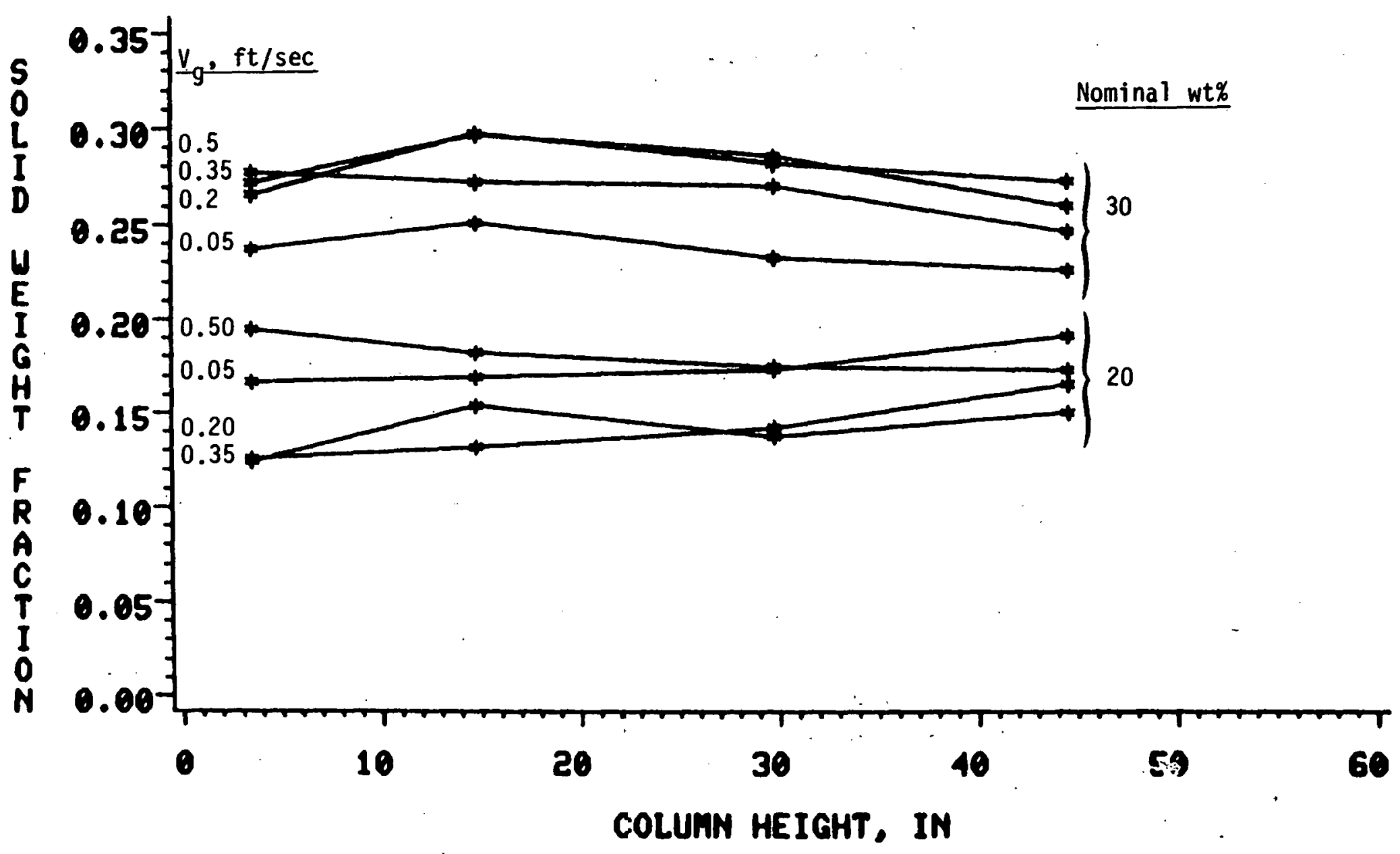




\section{INCH COLD FLOW SIMULATOR SOLID CONCBNTRATION PROFILES ISOPARATTIN, 45-53 " LUQUID FLOW $=0.0 \mathrm{mT} / \mathrm{SEC}$}

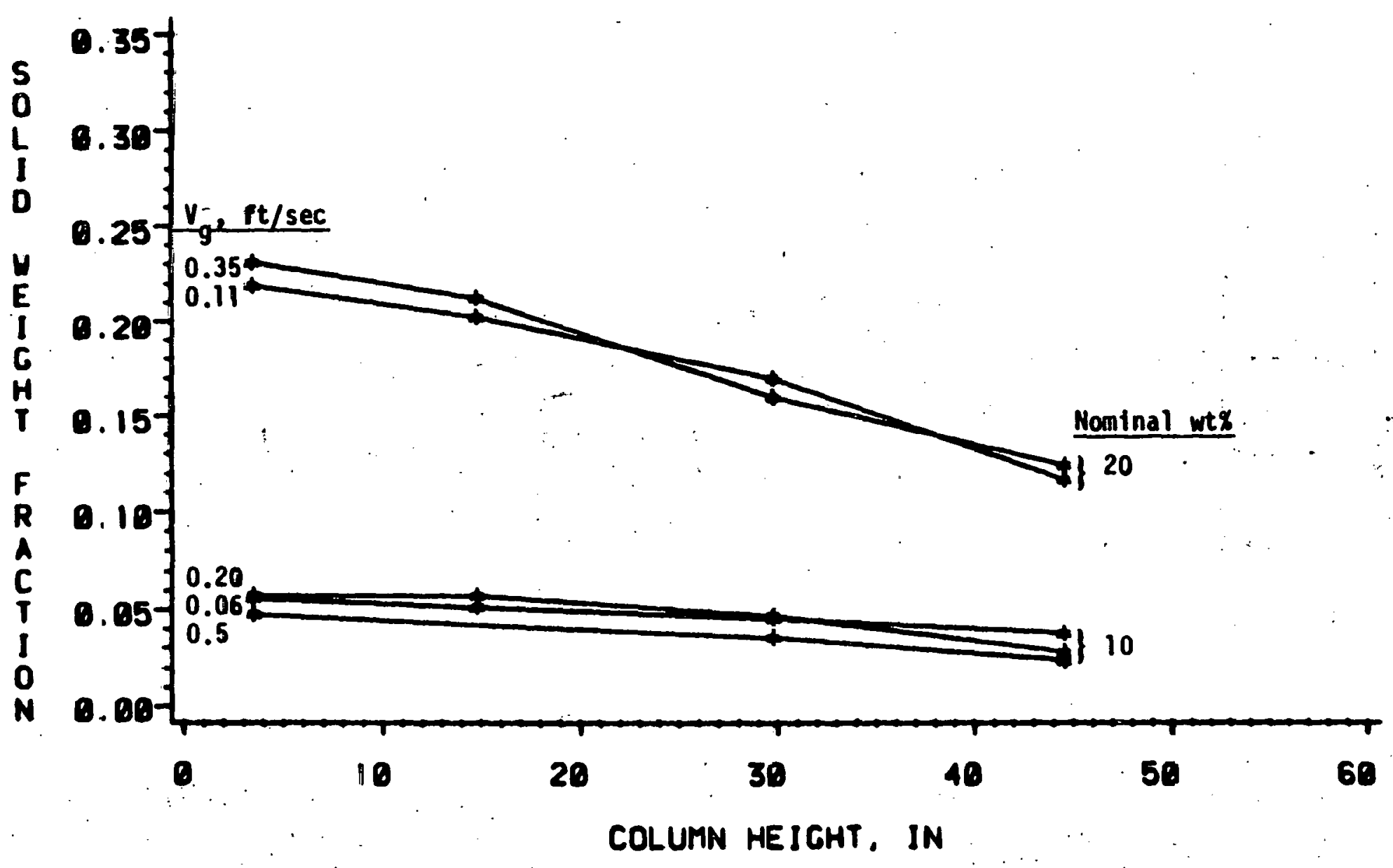




\section{FIGURE 13 \\ 5 INCH COLD FLOW SIMULATOR SOLID CONCENTRATION PROFILES 180PARUTIN LIQUID FLOW $=0.0 \mathrm{mT} / \mathrm{SEC}$}

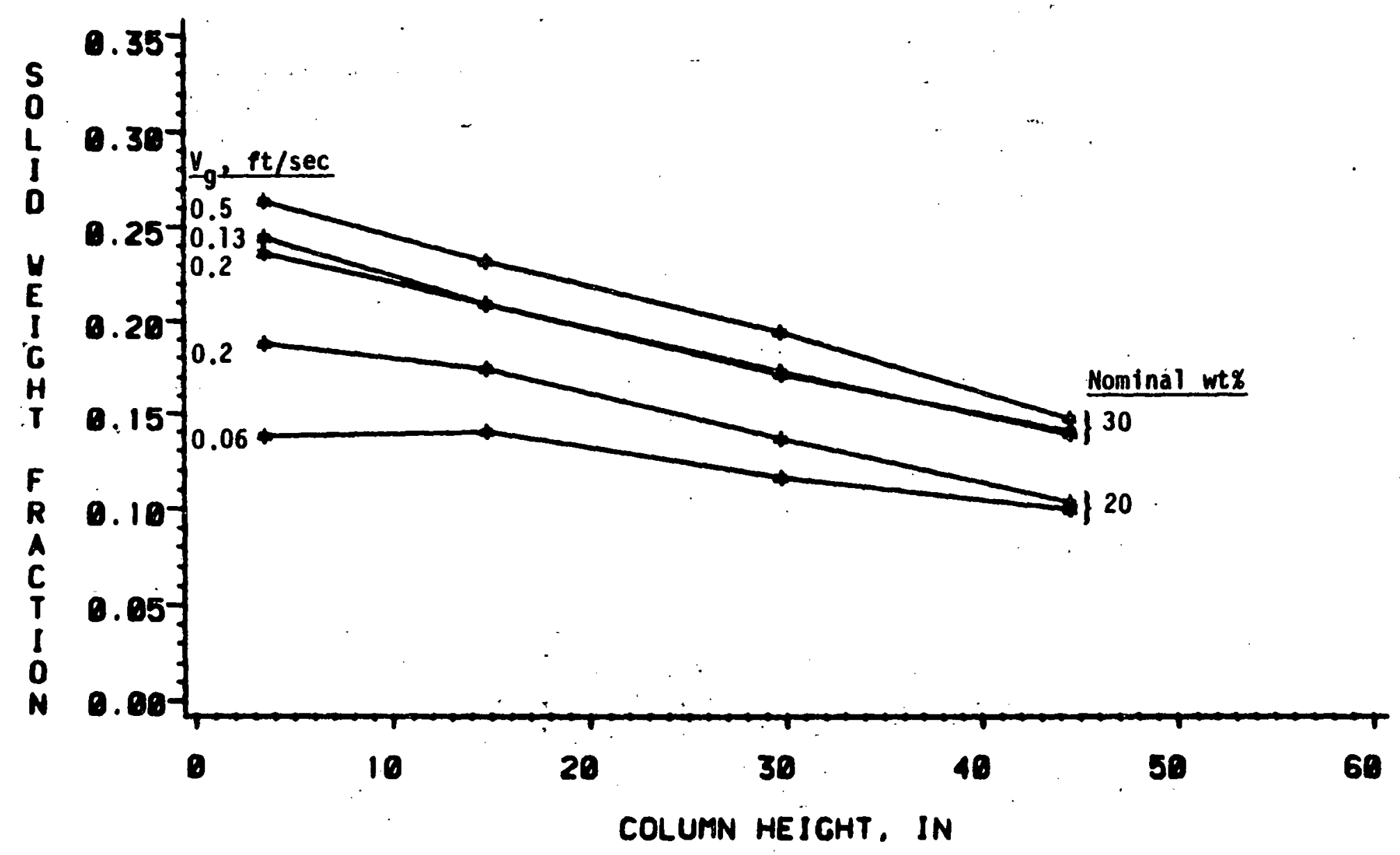




\section{INCH COLD FLOW SIMULATOR SOLID CONCENTRATION PROFILES \\ ISOPARATIN, 45-53 $\mu^{\prime}$ X SILICA,NR LQUID FLOW > $0.0 \mathrm{FT} /$ SEC}

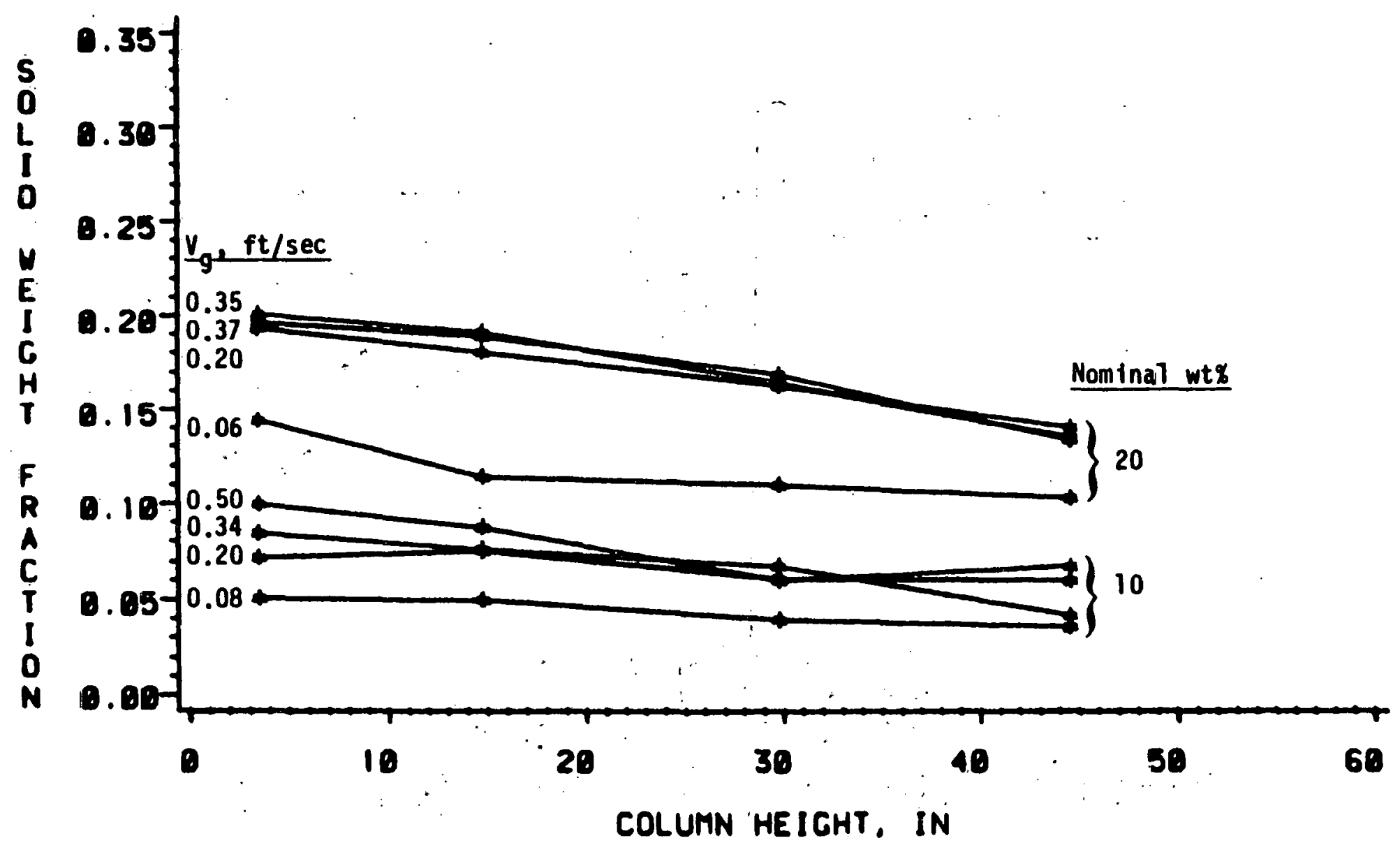




\section{INCH COLD FLOW SIMULATOR SOLDD CONCENTRATION PROPILES ISOPARUTPIN, 46-65 н M SILICA,N2 UQUID FLOW > $0.0 \mathrm{FT} / \mathrm{SEC}$}

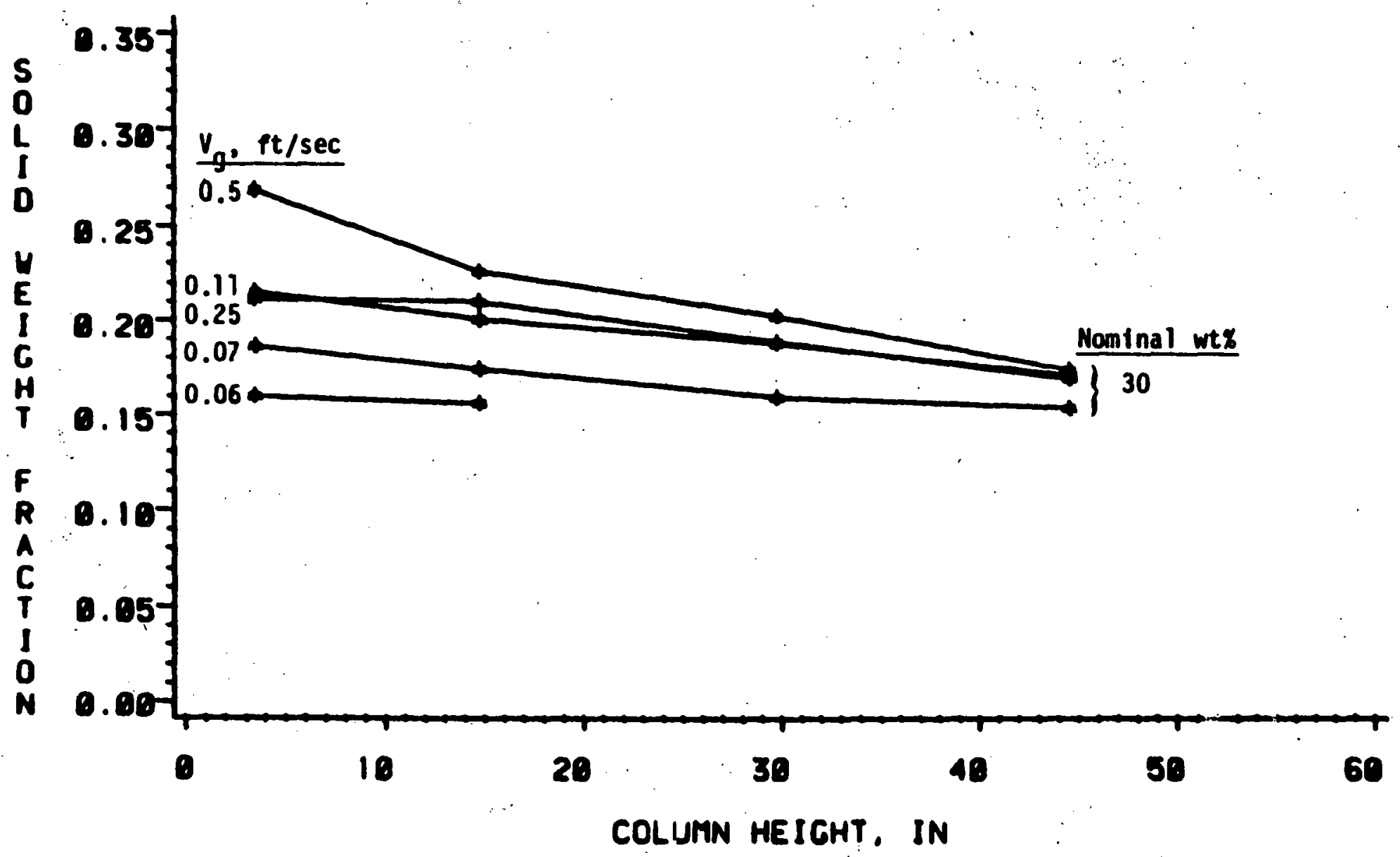




\section{INCH COLD FLOW SIMULATOR SOLID CONCENTRATION PROFILES ISOPARAFFIN, 98-115:HM SILICA,N2 LIQUID FLOW $=0.0 \mathrm{FT} / \mathrm{SEC}$}

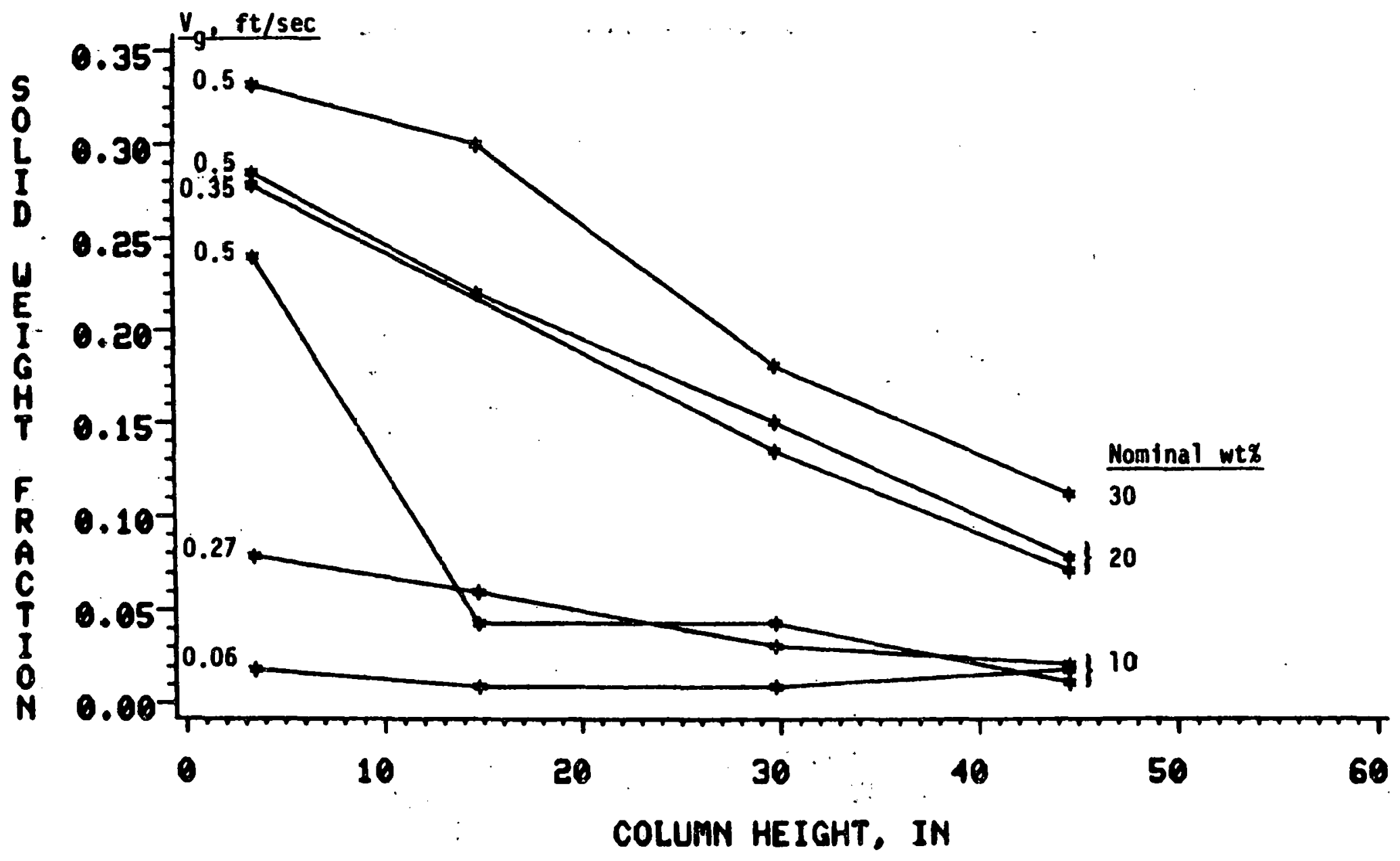




\section{INCH COLD FLOW SIMULATOR SOUD CONCENTRATION PROFILES IBOPARATTIN, D8-115 HM BILICA.NR LQUID FLOW $>0.0 \mathrm{FT} / \mathrm{SEC}$}

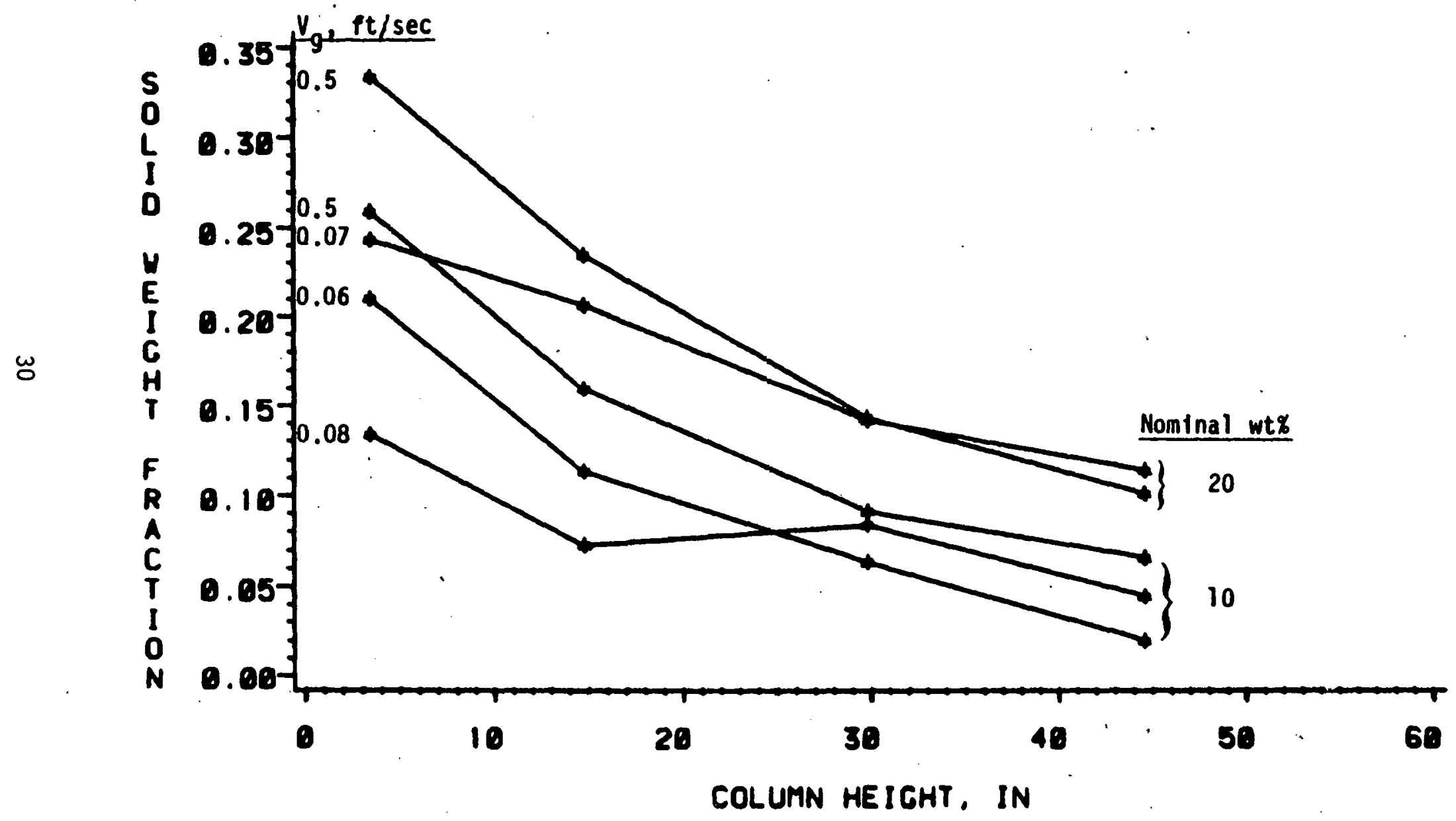




\section{INCH COLD FLOW SIMULATOR SOLD CONCENTRATION PROBILES

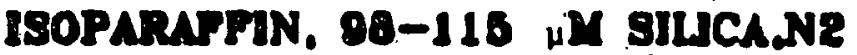 LQUID FLOW $>0.0 \mathrm{FT} / \mathrm{SEC}$}

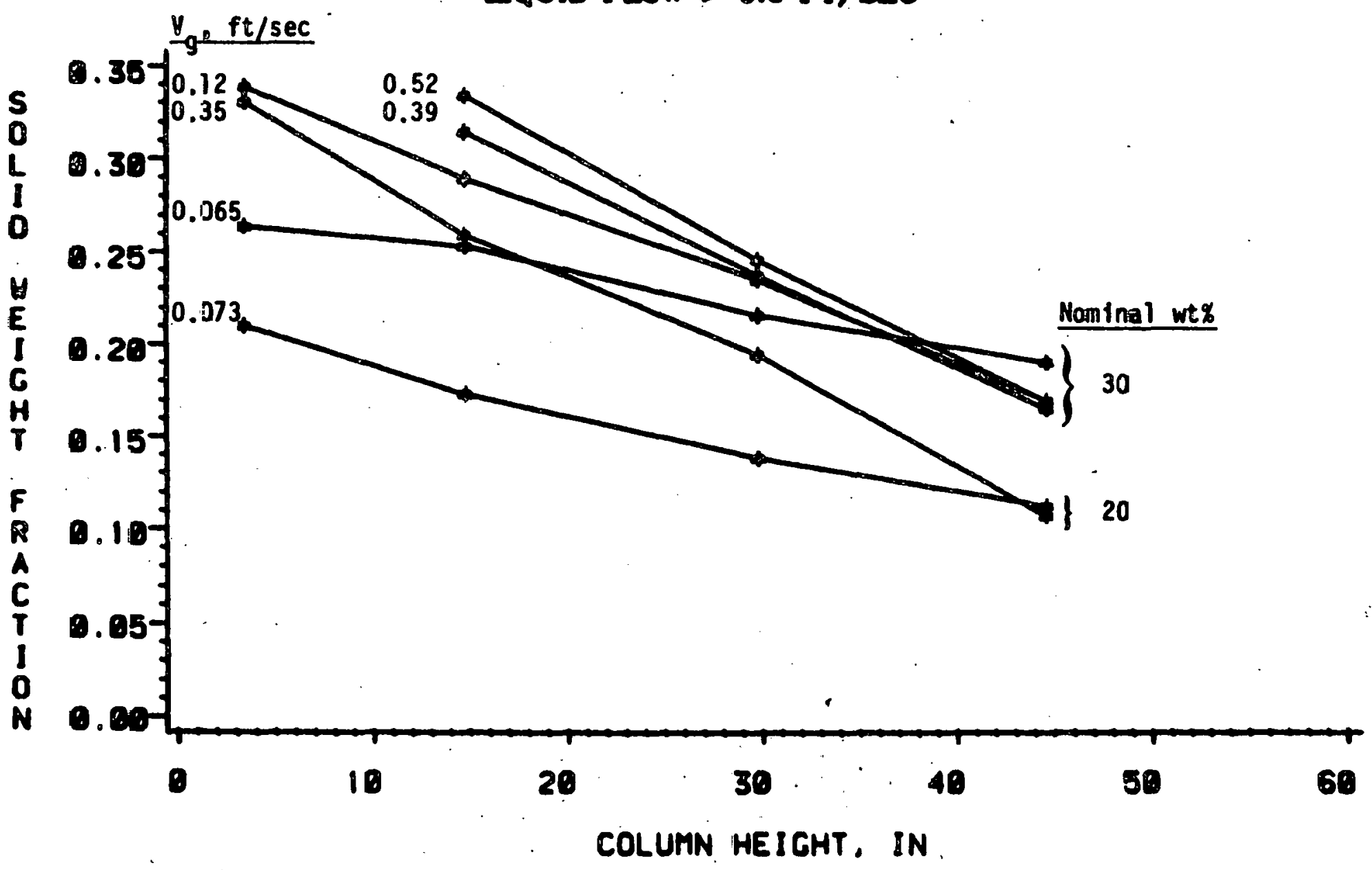




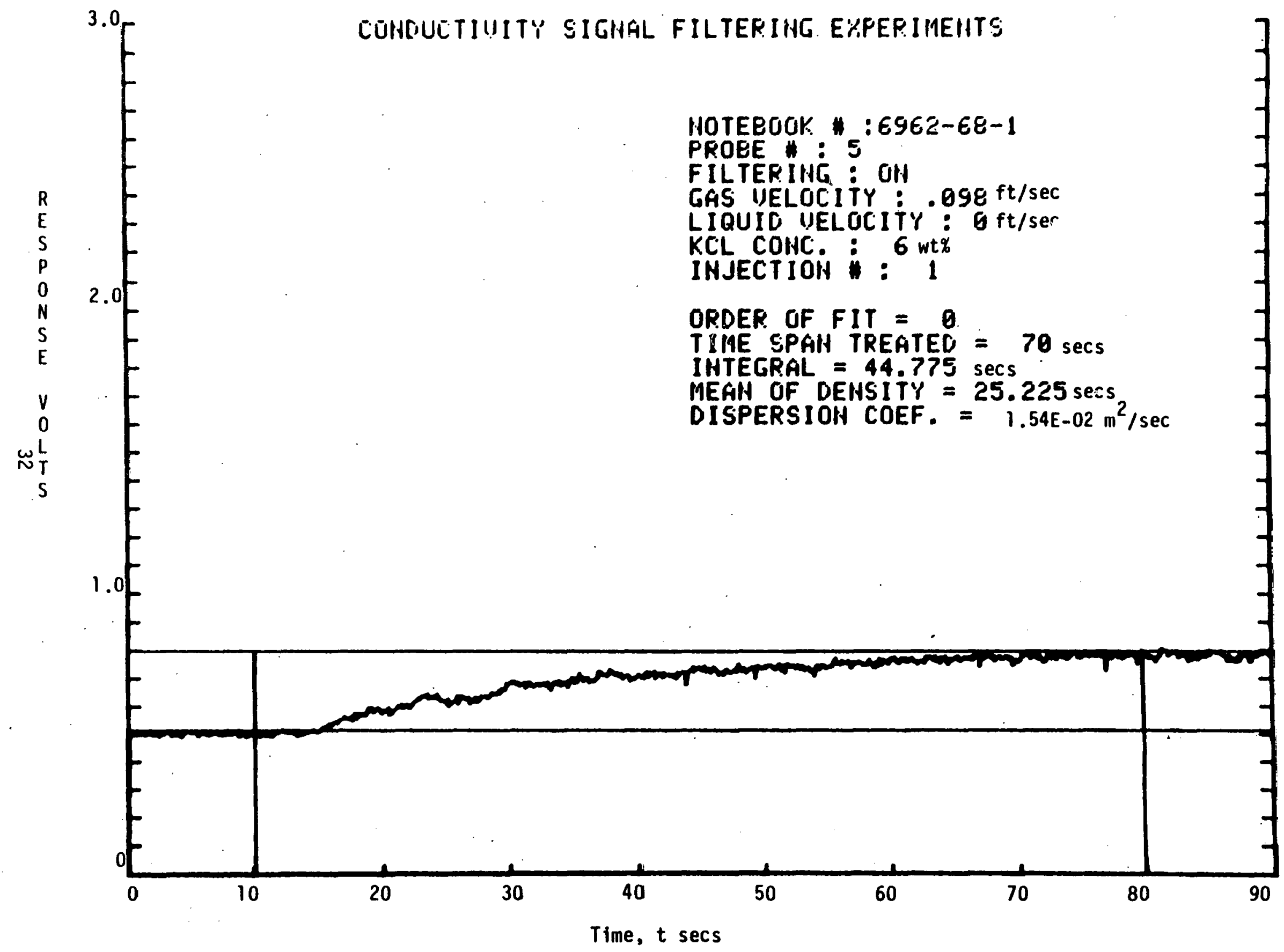


FIGURE 20

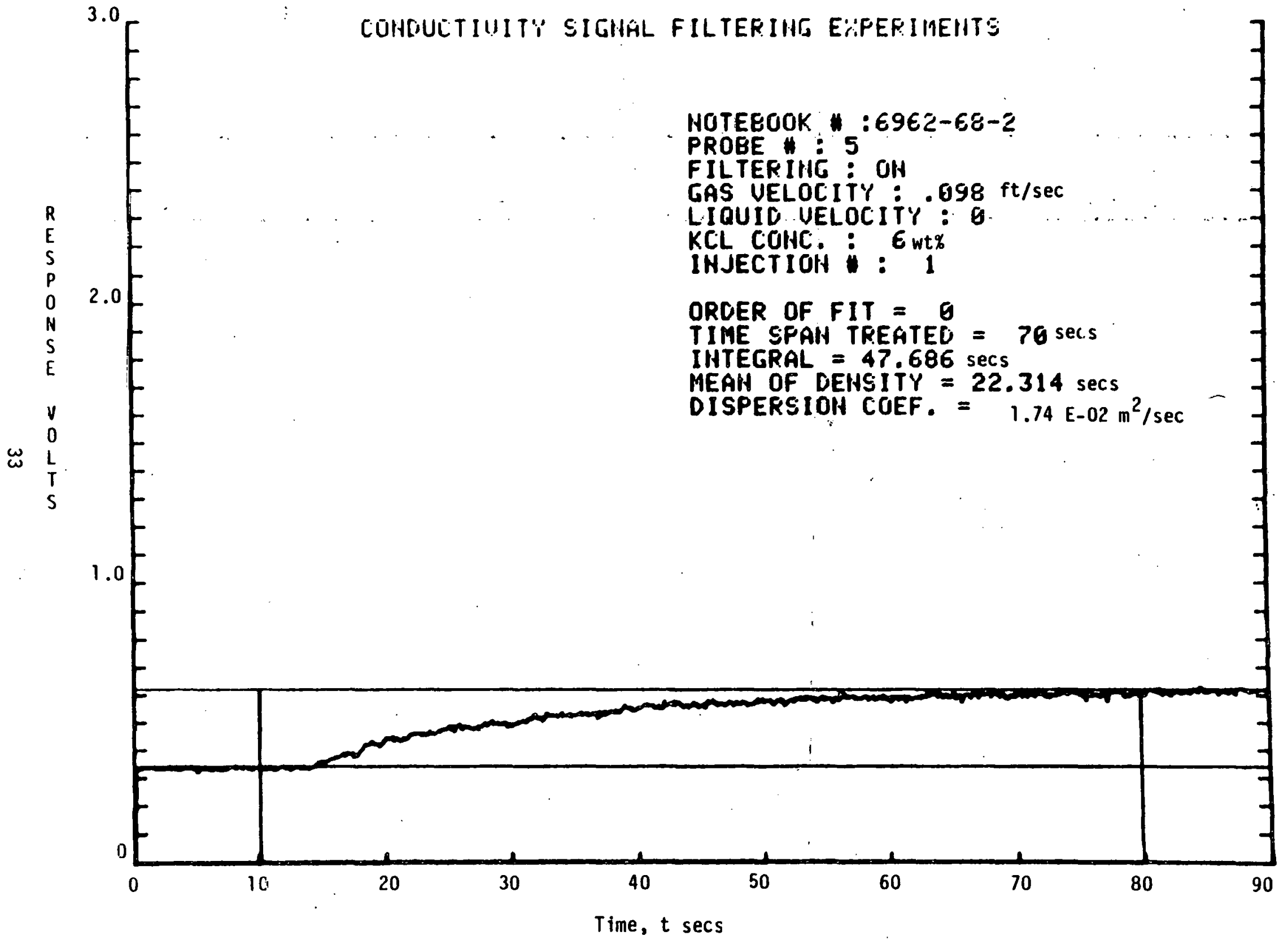




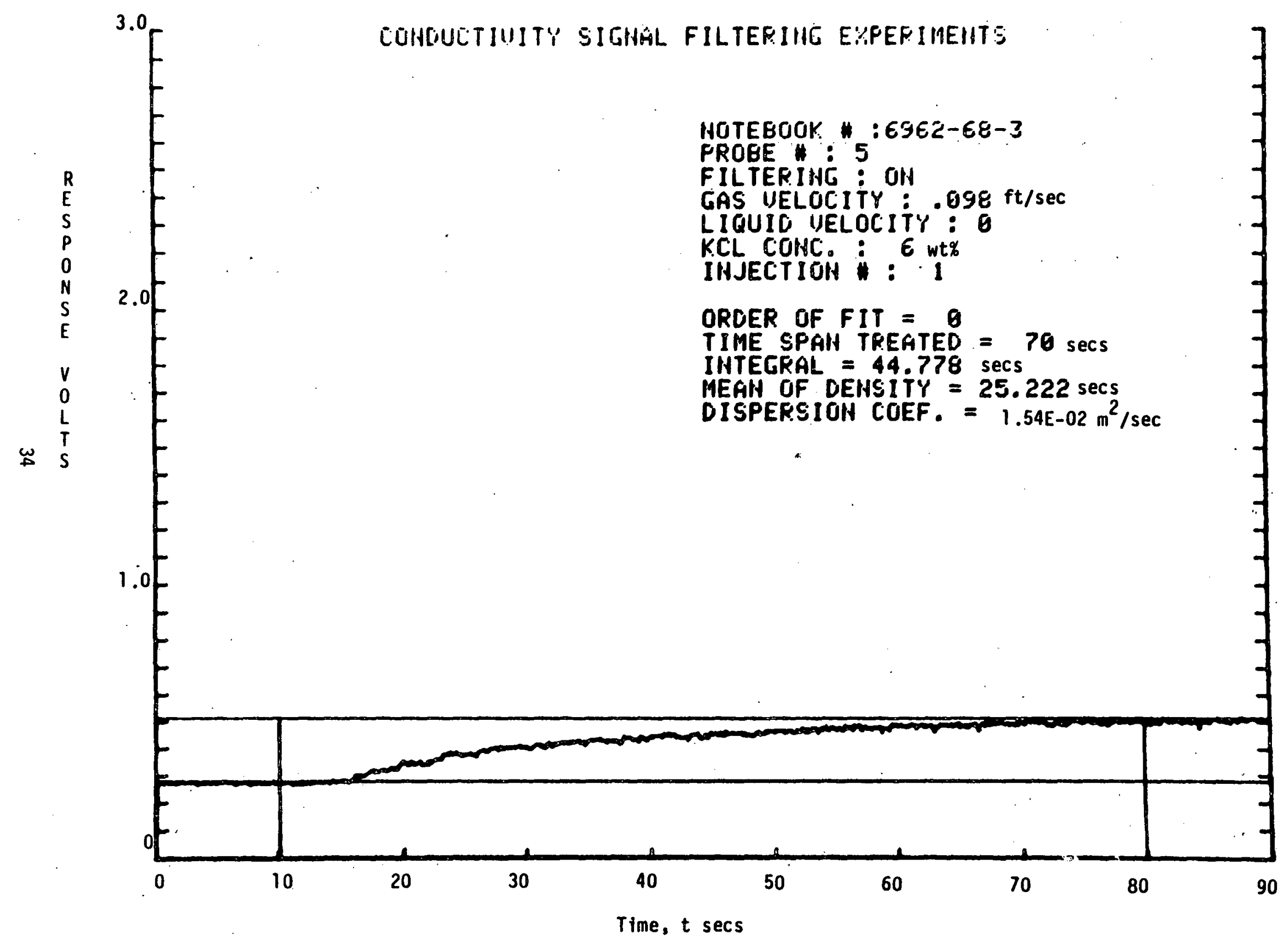


FIGURE 22

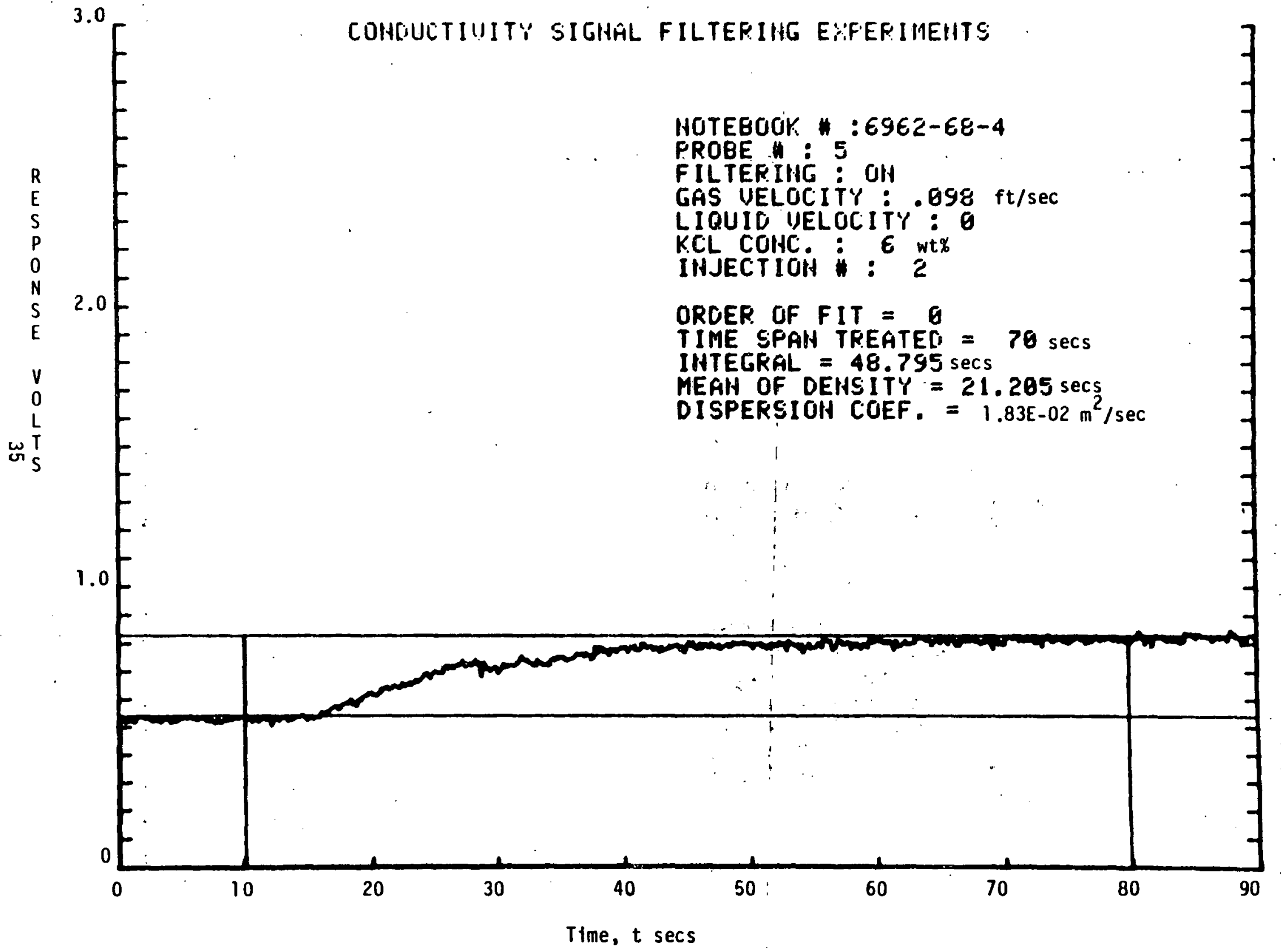


FIGIJRE 23

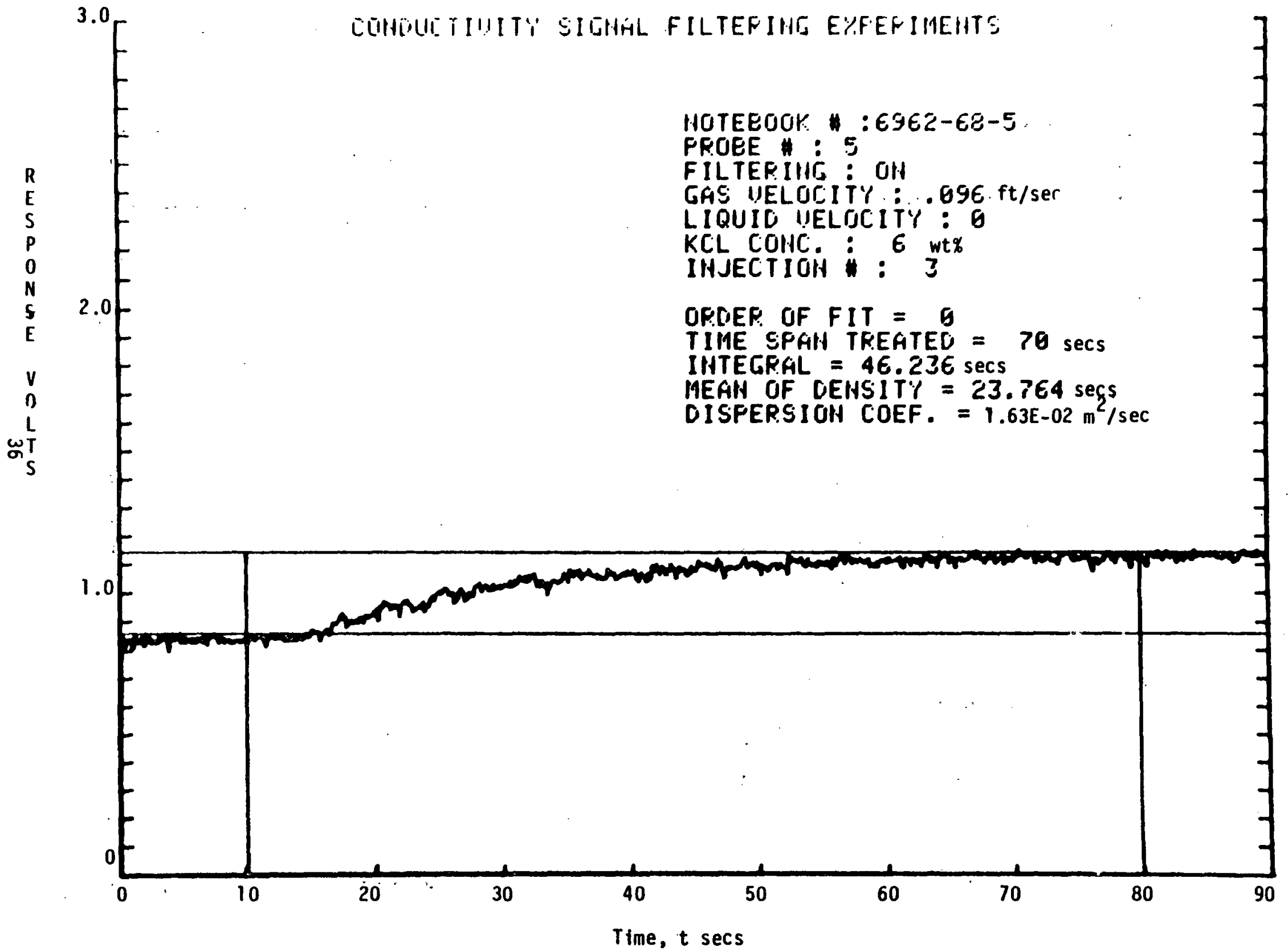




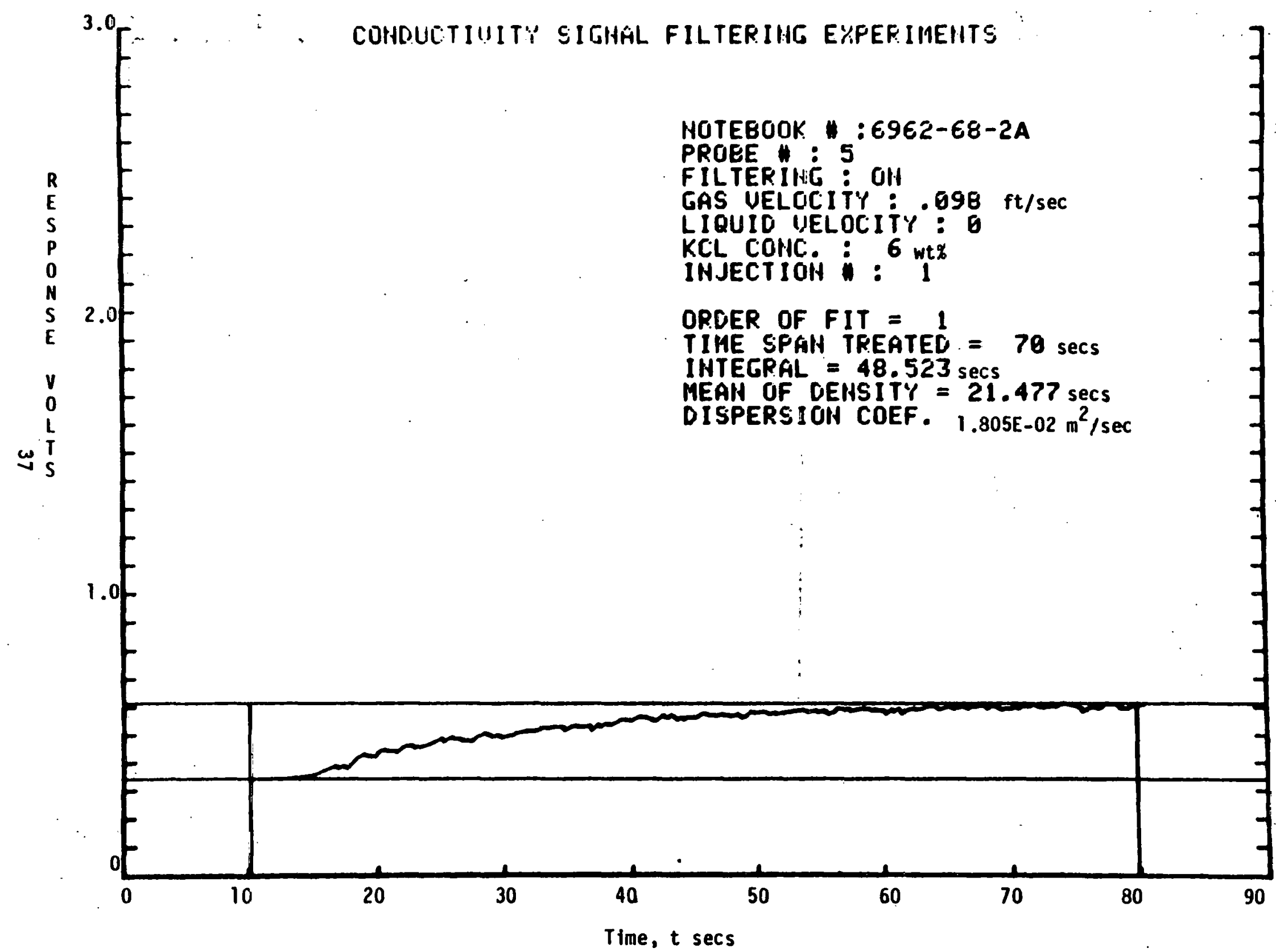




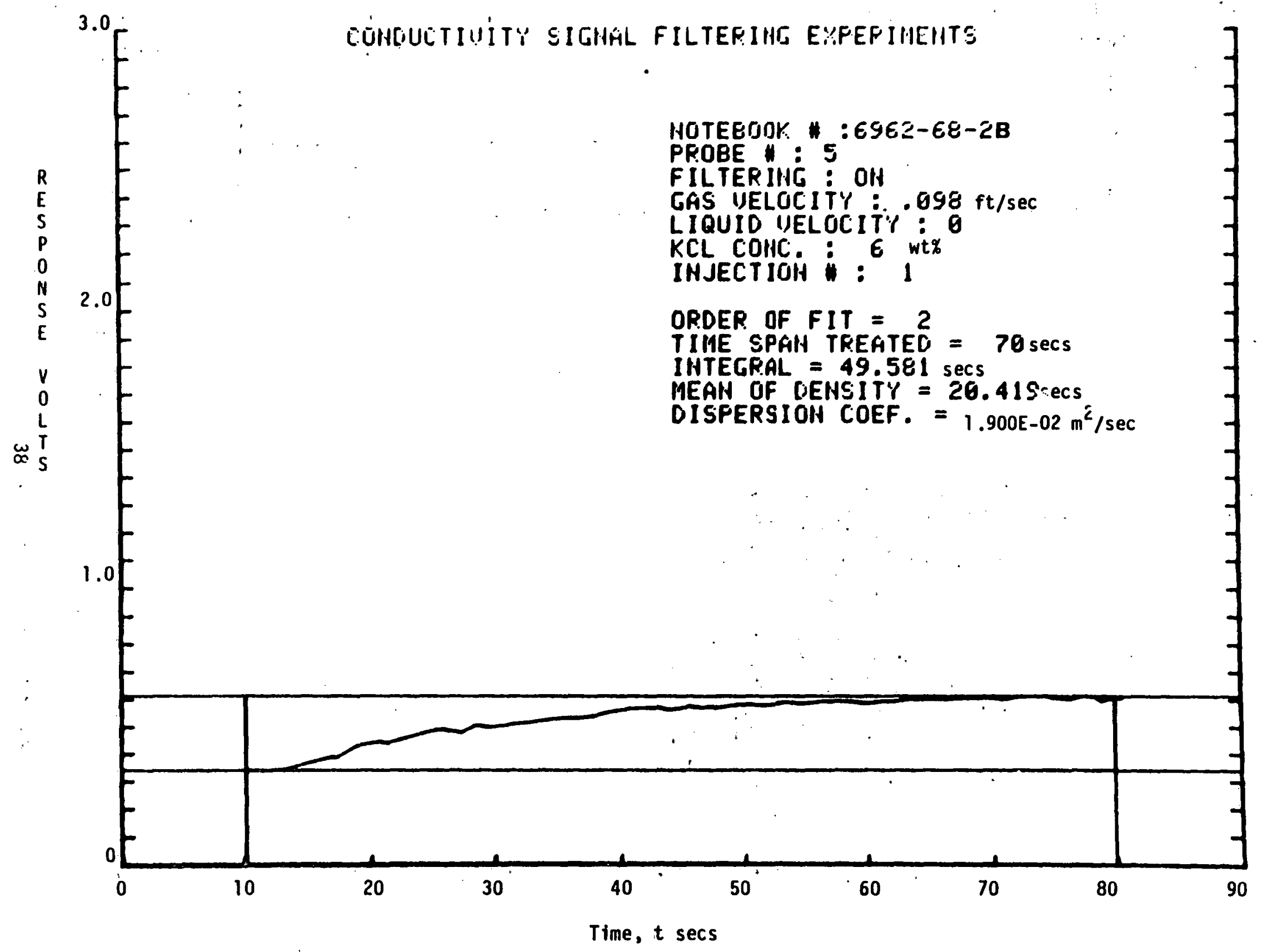




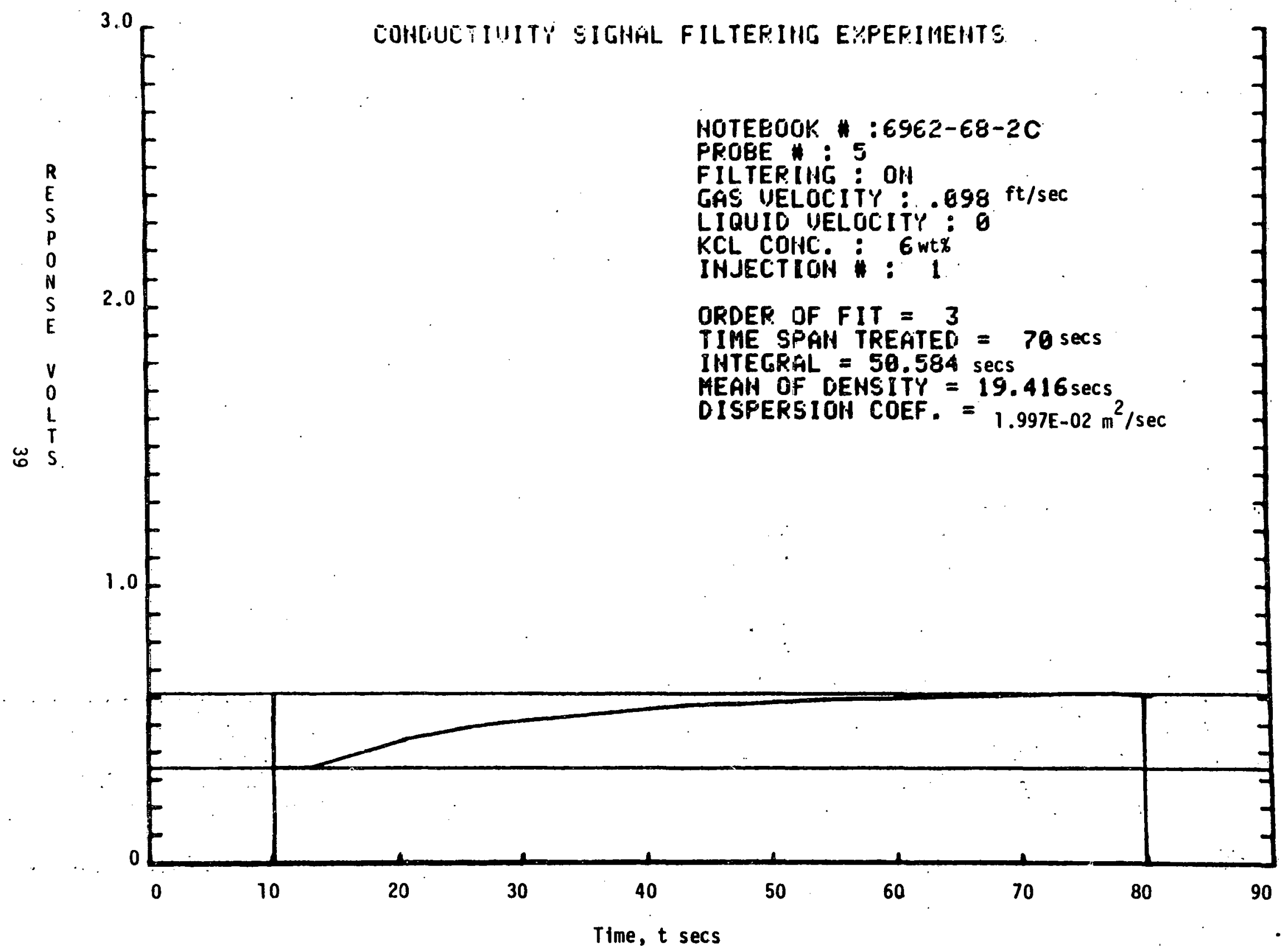




\section{INCH COLD FLOW SIMULATOR DISPERSION COEFFICIENT VS GAS VELOCITY \\ POR WATER-AIR SYSTEM \\ SHAKEDOWN RUNS}

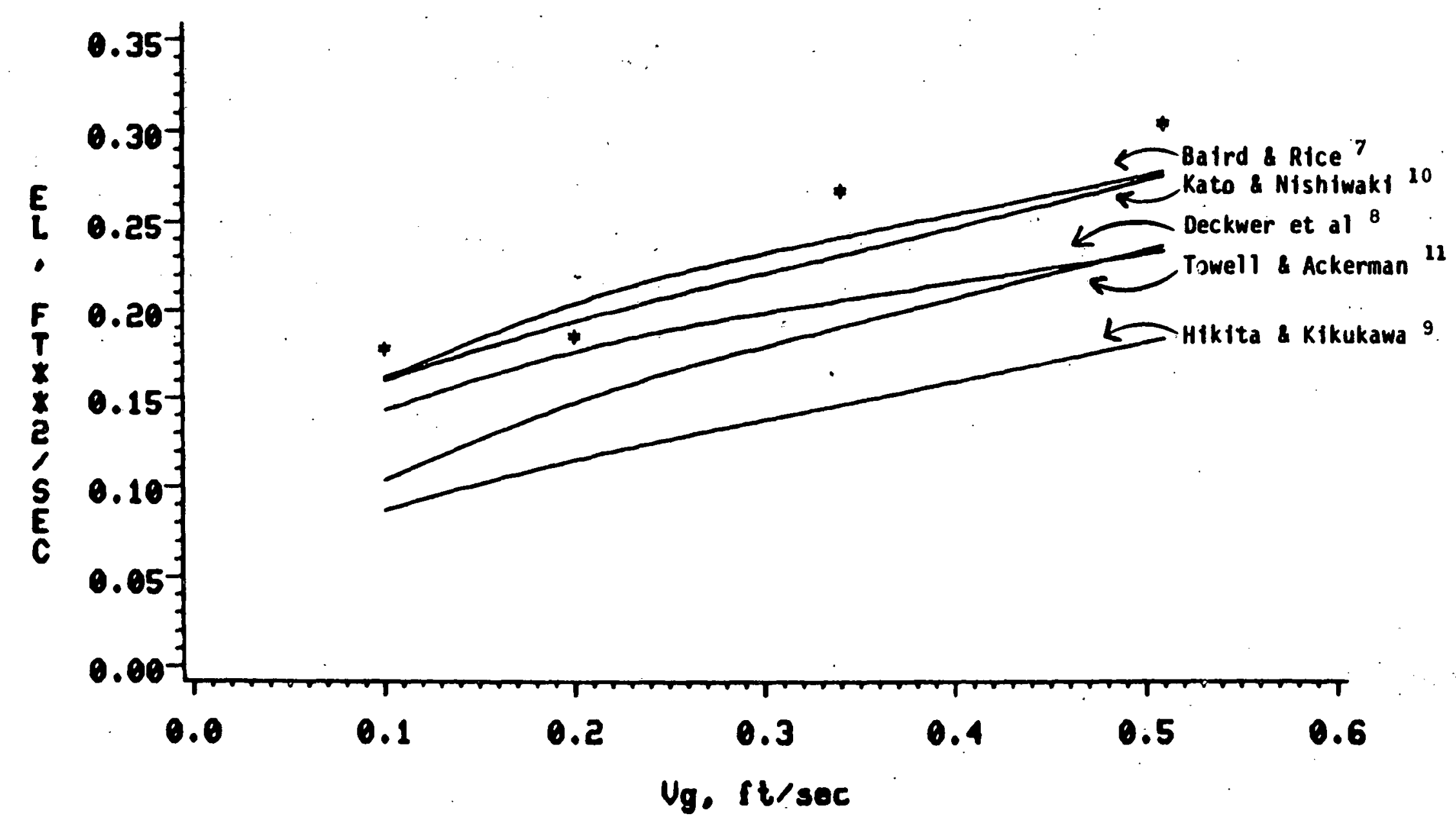




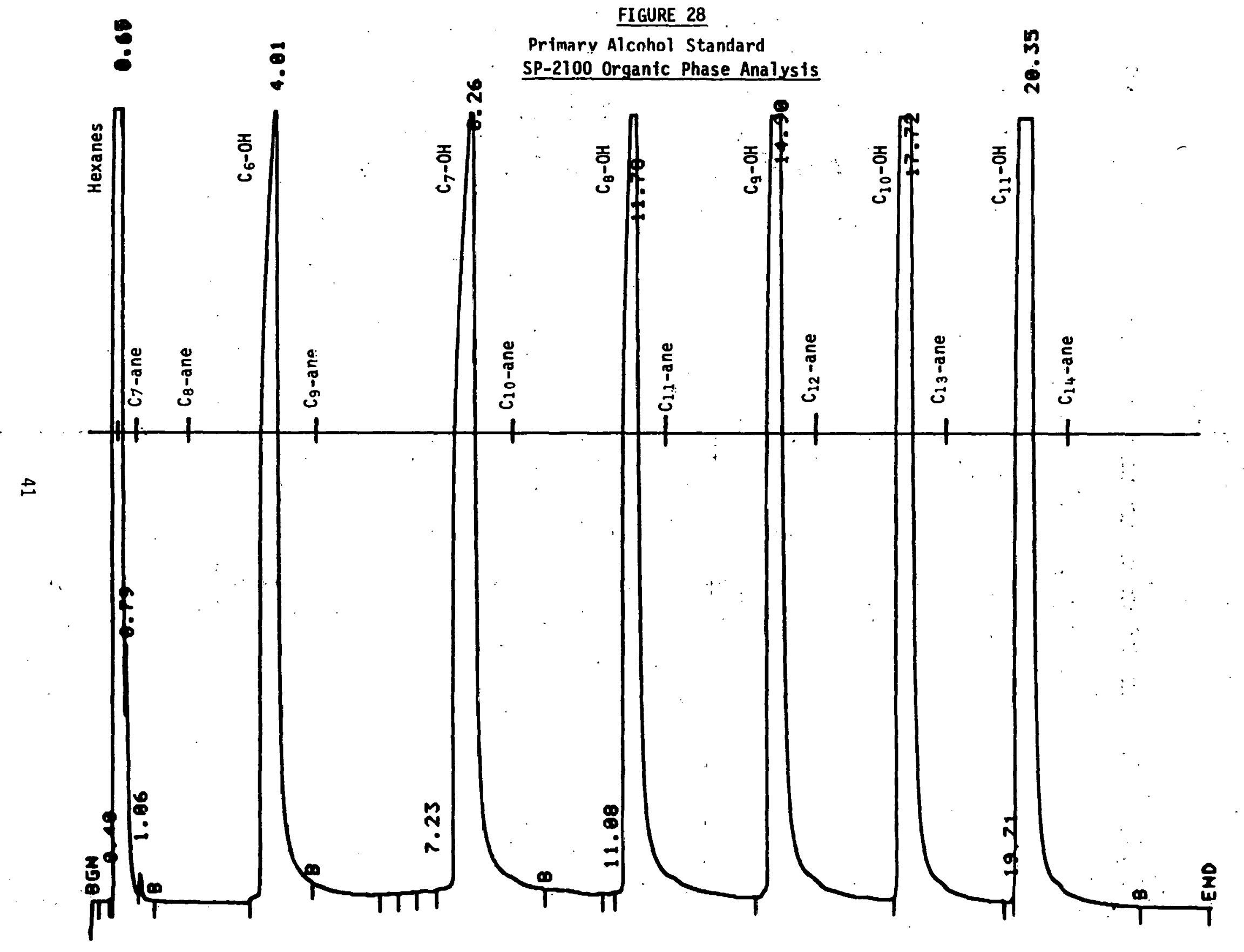


FI GURE 29

Hydrocarbon Product with Primary Alcohols Overlayed

SP-2100 Organic Phase Analys is :

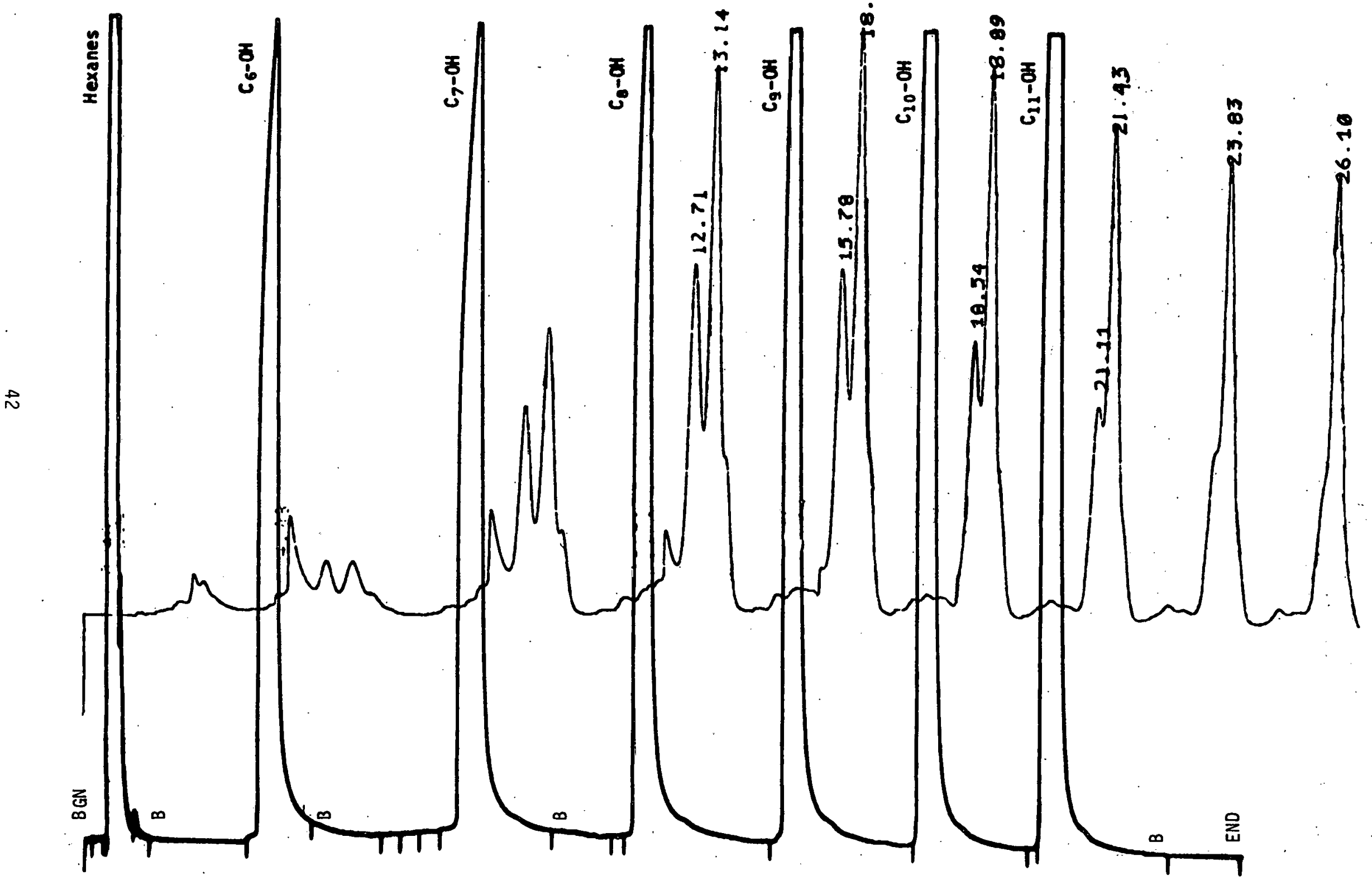


$\triangle$ AtirProducts

9.0 TABLES 
TABLF, 1

GAS HOLDUP: 5" COLD FLOW SIMILATOR

SYSTEM : THREF PHASE

LIQQUIR-ISOPARAFFIN

SCiLIR 0-5 $\mu M$ RFD IRON OXIDF.

GAS-NITROGEN

RUN

VG VL ES FT/SFC FT/SEC

EXP:

FG FG EG WEIGHT

AKITA \& HIRITA \& PILHOFER

YOSHIDA2 RIKITKAWA ${ }^{3}$ \& BACH ${ }^{4}$ FRACTION

\begin{tabular}{|c|c|c|c|c|c|c|c|}
\hline $6932-29-1$ & 0.070 & $n . n$ & 0.063 & 0.058 & 0.179 & 0.093 & 0.100 \\
\hline $6962-9-1$ & 0.380 & 0.100 & 0.192 & 0.181 & 0.397 & 0.248 & 0.100 \\
\hline $6984-16-1$ & 0.500 & 0.0 & 0.254 & 0.208 & 0.452 & 0.285 & 0.100 \\
\hline $6984-17-1$ & $0.35 n$ & 0.0 & 0.211 & 0.173 & 0.382 & 0.237 & $0.10 n$ \\
\hline $6984-18-1$ & 0.500 & 0.100 & 0.252 & 0.208 & 0.452 & 0.285 & 0.100 \\
\hline $6984-20-1$ & n. Inn & $n . n$ & 0.075 & 0.077 & 0.212 & 0.116 & 0.200 \\
\hline $6984-21-1$ & $0.35 n$ & 0.100 & 0.175 & 0.173 & 0.382 & 0.237 & 0.200 \\
\hline $6984-22-1$ & 0.500 & $0.10 n$ & 0.201 & 0.208 & 0.452 & 0.285 & 0.300 \\
\hline $6984-23-1$ & 0.058 & 0.0 & 0.055 & $0.05 n$ & 0.164 & ก.ก8.3 & 0.300 \\
\hline $6962-22-1$ & 0.340 & 0.100 & 0.146 & 0.170 & 0.377 & 0.234 & $0.3 n 0$ \\
\hline $6984-24-1$ & 0.500 & 0.0 & 0.234 & 0.208 & 0.452 & 0.285 & $0.3 n n$ \\
\hline 69R4-25-1 & $0.2 n n$ & $n . n$ & 0.131 & 0.124 & 0.294 & 0.175 & $0.3 n n$ \\
\hline
\end{tabular}


TABLE I (CON'T)

GAS HOLDUP: 5" COLD FLOW. STMULATOR

SYSTEM: THREE PHASE

LIQUID-ISOPARAFFIN

SOLID- 0-5 HM RED IRON OXIDE

GAS-NITROGFN

\begin{tabular}{|c|c|c|c|c|c|c|c|}
\hline RUN & $\begin{array}{c}\text { VG } \\
\text { FT/SEC }\end{array}$ & $\begin{array}{c}\text { VL } \\
\text { FT/SEC }\end{array}$ & $\begin{array}{c}\text { EG } \\
\text { EXP. }\end{array}$ & $\begin{array}{c}\text { EG } \\
\text { AKITA \& } \\
\text { YOSHIDA }\end{array}$ & $\begin{array}{c}\text { E.G } \\
\text { MIKITA } \\
\text { RIRINRAWA }\end{array}$ & $\begin{array}{c}\text { EG } \\
\text { PILHOFER } \\
\& \text { BACH }\end{array}$ & $\begin{array}{l}\text { WEIGHT } \\
\text { FRACTION }\end{array}$ \\
\hline $6984-26-1$ & 0.100 & 0.0 & $0.08 n$ & 0.077 & 0.212 & 0.116 & 0.300 \\
\hline $6962-27-1$ & 0.190 & 0.0 & 0.157 & 0.120 & 0.287 & 0.170 & 0.200 \\
\hline $6962-28-1$ & 0.182 & 0.100 & 0.100 & 0.117 & 0.281 & 0.165 & 0.200 \\
\hline $962-29-1$ & 0.064 & 0.0 & 0.064 & 0.054 & 0.172 & 0.088 & 0.200 \\
\hline $962-3 n-1$ & 0.444 & 0.0 & 0.230 & 0.196 & 0.427 & 0.268 & 0.200 \\
\hline $6,2-31=1$ & 0.360 & $0.1 n n$ & 0.154 & 0.176. & 0.387 & 0.241 & 0.200 \\
\hline $62-32-1$ & 0.474 & 0.100 & 0.194 & 0.203 & 0.441 & 0.277 & 0.200 \\
\hline
\end{tabular}


TARLF. 2

GAS HOLNUP: 5" COLN FLOW SIMULATOR

SYSTEM : THREF. PHASE

LIOUUID-ISOPARAFFIN

SOLID- 45-53 HM IRON OXIDF.

GAS-NITROCEN

\begin{tabular}{|c|c|c|c|c|c|c|c|}
\hline RUY: & $\begin{array}{c}\text { VG } \\
\text { FT/SEC }\end{array}$ & $\frac{v}{\mathrm{FT} / \mathrm{SEC}}$ & $\begin{array}{c}\text { FC. } \\
\text { EXP. }\end{array}$ & $\begin{array}{l}\text { EG } \\
\text { AKITA \& } \\
\text { YOSHIDA }\end{array}$ & $\begin{array}{l}\text { FG } \\
\text { HI२ITA \& } \\
\text { RIKUKAWA }\end{array}$ & $\begin{array}{c}\text { FC } \\
\text { PILHOFFR } \\
\& \text { BACF" }\end{array}$ & $\begin{array}{l}\text { WEITHT } \\
\text { FPACTION }\end{array}$ \\
\hline $6952-7-1$ & $0.1 \mathrm{nn}$ & 0.0 & 0.099 & 0.077 & 0.212 & 0.116 & 0.076 \\
\hline 6932-24-1 & 0.374 . & 0.065 & 0.209 & 0.179 & 0.394 & 0.246 & 0.114 \\
\hline $6932-25-1$ & $0.5 n n$ & n.n & 0.240 & 0.208 & 0.452 & 0.285 & 0.129 \\
\hline $6932-26-1$ & 0.120 & 0.075 & 0.121 & ก.กหล & 0.231 & 0.129 & n.1n4 \\
\hline $5992-99-2$ & 0.350 & $0 . n$ & 0.137 & 0.173 & 0.382 & 0.237 & 0.093 \\
\hline $5992-99-3$ & n. $2 \mathrm{nn}$ & 0.0 .59 & 0.156 & 0.124 & 0.294 & 0.175 & $0.11 n$ \\
\hline $5992-99-4$ & 0.050 & $0 . n$ & $0 . n 70$ & 0.044 & 0.153 & 0.075 & 0.044 \\
\hline $6962-8-1$ & 0.520 & 0.056 & 0.375 & 0.212 & 0.460 & 0.290 & 0.052 \\
\hline $6932-27-1$ & 0.322 & $n . n$ & 0.162 & 0.165 & 0.367 & 0.227 & 0.250 \\
\hline 5992-99-.5 & $0.05 n$ & 0.075 & $0.1 \mathrm{nn}$ & 0.044 & 0.153 & 0.075 & 0.175 \\
\hline 5992-n9-6 & $0.17 n$ & $n . n$ & 0.102 & $0 . n 77$ & 0.212 & 0.115 & $0.2 n 3$ \\
\hline $6984-2-1$ & 0.500 & $0 . n 76$ & 0.292 & $0.2 n R$ & 0.452 & 0.285 & 0.181 \\
\hline $60 n:-3-1$ & $n .2 n n$ & $n .:)$ & 0.159 & $n .124$ & 0.294 & 0.175 & 0.197 \\
\hline
\end{tabular}




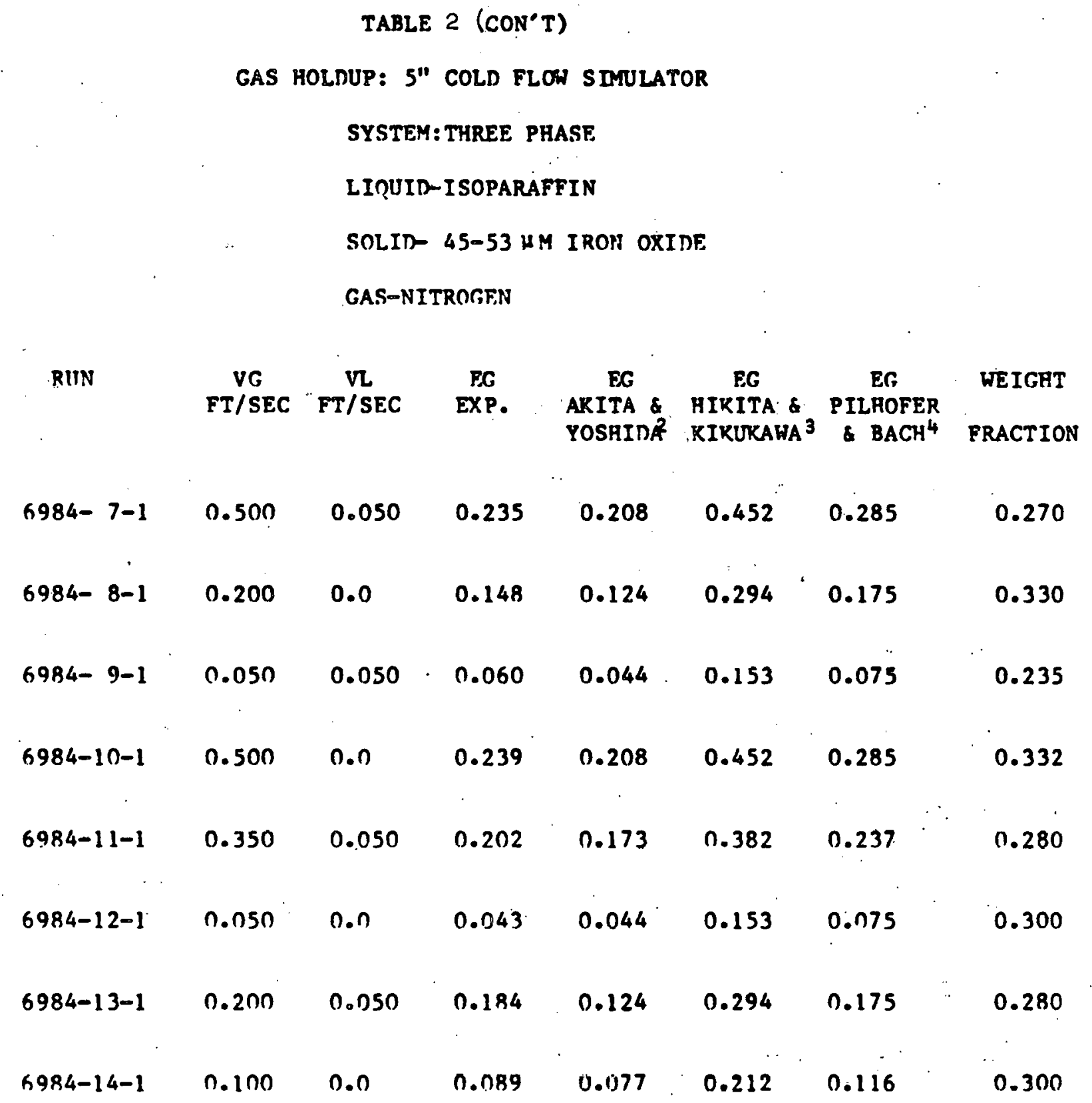


TABLE 3

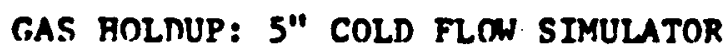

SYSTEM : THREF. PHASE

LIQUID-ISOPARAFFIN

SOLID- 45-53 म.Y SILICA

GAS-NITROGEN

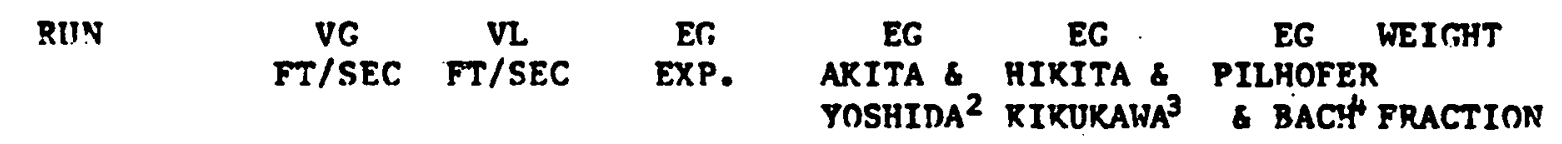

\begin{tabular}{|c|c|c|c|c|c|c|c|}
\hline $6962-48-1$ & 0.344 & 0.060 & 0.201 & 0.172 & 0.379 & 0.235 & 0.100 \\
\hline $6962-49-1$ & n.061 & $0 . n$ & $n .077$ & $n . n 52$ & n.168 & 0.085 & $0.10 n$ \\
\hline $6984-44-1$ & $0.5 n 0$ & $0.06 n$ & 0.231 & 0.208 & 0.452 & 0.285 & 0.100 \\
\hline $6984-45-1$ & 0.500 & 0.0 & 0.226 & 0.208 & 0.452 & 0.285 & 0.100 \\
\hline $6984-46-1$ & 0.200 & n.nkn & 0.171 & 0.124 & 0.294 & 0.175 & 0.100 \\
\hline $6984-47-1$ & 0.100 & 0.0 & 0.082 & 0.077 & 0.212 & 0.116 & 0.100 \\
\hline $6962-5 n-1$ & 0.077 & 0.060 & 0.078 & 0.063 & 0.188 & 0.099 & 0.100 \\
\hline $6962-51-1$ & 0.207 & 0.0 & 0.144 & 0.127 & 0.299 & 0.178 & 0.100 \\
\hline $6962-52-1$ & 0.517 & $0 . n 5 n$ & 0.237 & 0.212 & 0.459 & 0.289 & $0.2 n 0$ \\
\hline $6962-53-1$ & 0.346 & $0 . n$ & 0.194 & 0.172 & 0.380 & 0.236 & 0.200 \\
\hline $6962-54-1$ & ก.368 & $0.05 n$ & 0.202 & 0.178 & 0.391 & 0.244 & $0.2 \mathrm{~m}$ \\
\hline
\end{tabular}


TABLE. 3 (CONT'D)

GAS HOLNUP: 5" COLN FLON SIMULATOR

SYSTFM: THRFE PHASE

LIQUID-ISOPARAFFIN

SOLID- 45-53 нM SILICA

GAS-NITROGFN

\begin{tabular}{|c|c|c|c|c|c|c|c|}
\hline RUR? & $\begin{array}{c}\text { vG } \\
\text { FT/SFC }\end{array}$ & $\underset{\mathrm{FT} / \mathrm{SEC}}{\mathrm{VL}}$ & $\begin{array}{l}\text { E.F } \\
\text { EX.P. }\end{array}$ & $\begin{array}{c}\text { EG } \\
\text { AKITA \& } \\
\text { YOSHIDA } 2\end{array}$ & $\begin{array}{l}\text { FG } \\
\text { HIKITA \& } \\
\text { RIKUKAHA }\end{array}$ & $\begin{array}{c}\text { EG } \\
\text { PILHOFER } \\
\& \text { BACH }^{+}\end{array}$ & $\begin{array}{l}\text { WEIGHT } \\
\text { REACTIOH }\end{array}$ \\
\hline $6962-55-1$ & 0.113 & 0.0 & 0.108 & 0.084 & 0.225 & 0.125 & 0.200 \\
\hline $6962-56-1$ & 0.202 & 0.050 & 0.165 & 0.125 & 0.295 & 0.176 & 0.200 \\
\hline $6984-48-1$ & $0.20 n$ & 0.0 & 0.130 & 0.124 & 0.294 & 0.175 & 0.200 \\
\hline $6984-49-1$ & 0.060 & 0.050 & 0.046 & 0.051 & 0.167 & 0.084 & 0.200 \\
\hline $6984-5 n-1$ & 0.060 & $0 . n$ & 0.067 & 0.051 & 0.167 & 0.084 & $0.2 n n$ \\
\hline $6964-51-1$ & n.ก6n & $n . n$ & 0.052 & 0.051 & 0.167 & ก.ก84 & 0.300 \\
\hline $6962-57-1$ & 0.072 & n.n5n & 0.082 & $0.06 n$ & 0.182 & 0.095 & 0.300 \\
\hline $\begin{array}{l}\text { 6962-58-1 } \\
:\end{array}$ & $0.2 n 9$ & 0.0 & 0.140 & 0.128 & 0.300 & 0.179 & 0.300 \\
\hline $6962-59-1$ & 0.205 & $0.05 n$ & 0.142 & 0.126 & 0.297 & 0.177 & $0.30 n$ \\
\hline $6962-60-1$ & 0.510 & $0 . n$ & 0.223 & 0.210 & 0.456 & 0.288 & $0.3 n 0$ \\
\hline $6962-61-1$ & 0.118 & 0.050 & 0.125 & 0.087 & 0.229 & 0.128 & 0.300 \\
\hline $6962-62-1$ & 0.125 & 0.0 & 0.104 & 0.091 & 0.236 & 0.133 & 0.3100 \\
\hline $6962-63-1$ & $0.5 n k$ & n.n5n & 0.226 & 0.209 & 0.454 & 0.286 & 0.300 \\
\hline
\end{tabular}


TABLF. 4

CAS HOLDUP: 5" COLN FLOW SIMULATOR

SYSTEM:THREF. PHASE.

LIQQUID-ISOPARAFFIY:

SOLID- 90-106 HM SILICA

GAS-NITROGEN

\begin{tabular}{|c|c|c|c|c|c|c|}
\hline RUN & $\begin{array}{c}\text { VG } \\
\text { FT/SEC }\end{array}$ & $\stackrel{v}{\mathrm{rT} / \mathrm{SEC}}$ & $\begin{array}{l}\text { EC: } \\
\text { EXP. }\end{array}$ & $\begin{array}{c}\text { EG } \\
\text { ARITA \& } \\
\text { YOSHIDA } 2\end{array}$ & $\begin{array}{c}\text { EG } \\
\text { HIKITA \& } \\
\text { RIRURAWA }\end{array}$ & $\begin{array}{c}\text { EG } \\
\text { PILAOFFI } \\
\text { \& BACH }\end{array}$ \\
\hline
\end{tabular}

$\begin{array}{cccccccc}6984-31-1 & 0.500 & 0.040 & 0.223 & 0.208 & 0.452 & 0.285 & 0.100 \\ 6984-32-1 & 0.500 & 0.0 & 0.254 & 0.208 & 0.452 & 0.285 & 0.100 \\ 6984-33-1 & 0.100 & 0.050 & 0.117 & 0.077 & 0.212 & 0.116 & 0.100 \\ 6984-34-1 & 0.060 & 0.0 & 0.073 & 0.051 & 0.167 & 0.084 & 0.100 .\end{array}$

$\begin{array}{llllllll}6984-35-1 & 0.060 & 0.040 & 0.046 & 0.051 & 0.167 & 0.084 & 0.100\end{array}$

$\begin{array}{llllllll}6962-35-1 & 0.048 & 0.050 & 0.071 & 0.043 & 0.150 & 0.073 & 0.100\end{array}$

$\begin{array}{llllllll}6962-36-1 & 0.270 & 0 . n & 0.149 & 0.150 & 0.338 & 0.207 & 0.100\end{array}$

$\begin{array}{llllllll}6962-39-1 & 0.195 & 0.06 n & 0.141 & 0.122 & 0.29 n & 0.172 & 0.200\end{array}$

$\begin{array}{rrrrrrrr}6962-4 n-1 & 0.497 & 0.06 n & 0.23 n & 0.208 & 0.451 & 0.284 & 0.200\end{array}$

$\begin{array}{llllllll}6962-41-1 & 0.073 & 0.05 n & 0.079 & 0.06 n & 0.183 & 0.095 & 0.200\end{array}$

$\begin{array}{cccccccc}6962-42-1 & 0.354 & 0.06 n & 0.192 & 0.174 & 0.384 & 0.239 & 0.200\end{array}$ 
TABLF. 4 (CONT'D)

GAS HOLNUP: 5" COLN FLNW SIMULATOR

SYSTEM: THRF,F, PHASF,

LIDUIT-ISOPARAFFIN

SOLIR- 90-106 HY SILICA

GAS-NITROCEN

\begin{tabular}{|c|c|c|c|c|c|c|c|}
\hline RUSN & $\begin{array}{c}\text { VG } \\
\mathrm{FT} / \mathrm{SEC}\end{array}$ & $\begin{array}{c}\mathrm{vL} \\
\mathrm{FT} / \mathrm{SEC}\end{array}$ & $\begin{array}{c}\text { EG } \\
\text { EXP. }\end{array}$ & $\begin{array}{c}\text { EG } \\
\text { AKITA \& } \\
\text { YOSHIDA }\end{array}$ & $\begin{array}{c}\text { EC } \\
\text { HIRITA \& } \\
\text { RIKURAWA }\end{array}$ & $\begin{array}{l}\text { EC } \\
\text { PILHOFER } \\
\text { \& BACH't }\end{array}$ & $\begin{array}{l}\text { WEIGHT } \\
\text { FRACTION }\end{array}$ \\
\hline $6984-37-1$ & 0.500 & 0.0 & 0.212 & 0.208 & 0.452 & 0.285 & 0.200 \\
\hline $6984-38-1$ & $0.35 n$ & 0.0 & 0.178 & 0.173 & 0.382 & 0.237 & 0.200 \\
\hline$\cdot$ & & & ". & & . & . & \\
\hline $6984-39-1$ & 0.200 & $0 . n$ & $\begin{array}{c}0.113 \\
.\end{array}$ & 0.124 & 0.294 & 0.175 & 0.200 \\
\hline $6984-40-1$ & n.1nn & $0 . n$ & 0.060 & 0.077 & 0.212 & 0.116 & 0.200 \\
\hline $6962-43-1$ & 0.518 & n.n.5n & 0.216 & 0.212 & 0.459 & $0.29 n$ & 0.300 \\
\hline $6962-44-1$ & 0.118 & 0.nan & $0.12_{2}$ & n. $n 87$ & 0.229 & 0.128 & $0.3 n n$ \\
\hline $6962-45-1$ & 0.394 & 0.060 & 0.189 & 0.184 & $0.4 n 4$ & 0.252 & $n .30 n$ \\
\hline $6962-46-1$ & 0.065 & 0.060 & 0.057 & 0.055 & 0.173 & 0.089 & 0.300 \\
\hline $9962-47-1$ & $n: 496$ & $n . n$ & 0.214 & 0.207 & $0.45 n$ & 0.284 & 0.300 \\
\hline
\end{tabular}


TAB LE 5

LITERATURE COMPARISON FOR. SHIELDED,

\section{INTERNAL PROBES IN 5" COLUMN}

$$
\begin{aligned}
& \text { System: Air-Water } \\
& V_{L}=0.0 \mathrm{ft} / \mathrm{sec}
\end{aligned}
$$

\begin{tabular}{|c|c|c|c|c|c|c|}
\hline \multirow[b]{2}{*}{$\begin{array}{c}V_{G} \\
(\mathrm{ft} / \mathrm{sec}) \\
\end{array}$} & \multicolumn{6}{|c|}{ Liquid Dispersion Coefficient, $E_{L}\left(f t^{2} / \mathrm{sec}\right)$} \\
\hline & Exper & $\begin{array}{l}\text { Baird } 8 \\
\text { Rice } 7\end{array}$ & $\begin{array}{l}\text { Deckwer } \\
\text { et al }{ }^{8}\end{array}$ & $\begin{array}{l}\text { Hikita } \& \\
\text { Kikukawa } 9\end{array}$ & $\begin{array}{l}\text { Kato } \& \\
\text { Nishiwaki } \\
\text { 10 }\end{array}$ & $\begin{array}{l}\text { Towell \& } \\
\text { Ackerman ? }\end{array}$ \\
\hline 0.10 & 0.178 & 0.161 & 0.143 & 0.0875 & 0.160 & 0.104 \\
\hline 0.20 & 0.185 & 0.203 & 0.176 & 0.115 & 0.193 & 0.147 \\
\hline 0.34 & 0.267 & 0.240 & 0.205 & 0.146 & 0.230 & 0.190 \\
\hline 0.51 & 0.304 & 0.278 & 0.233 & 0.184 & 0.276 & 0.236 \\
\hline
\end{tabular}

